\title{
STORING SOLID RADIOACTIVE WASTES AT THE SAVANNAH RIVER PLANT
}

J. H. HORTON

J. C. COREY

TIS FILE

RECORD COPY

(10POND

SAVANNAH RIVER LABORATORY

AIKEN, SOUTH CAROLINA 29801 


\section{NOTICE}

This report was prepared as an account of work sponsored by the United States Government. Neither the United States nor the United States Energy Research and Development Administration, nor any of their contractors, subcontractors, or their employees, makes any warranty, express or implied, or assumes any legal liability or responsibility for the accuracy, completeness or usefulness of any information, apparatus, product or process disclosed, or represents that its use would not infringe privately owned rights.

\section{Printed in the United States of America}

Available from

National Technical Information Service

U. S. Department of Commerce

5285 Port Royal Road

Springfield, Virginia 22161

Price: Printed Copy \$4.00; Microfiche $\$ 2.25$ 


\section{STORING SOLID RADIOACTIVE WASTES AT THE SAVANNAH RIVER PLANT}

by

J. H. Horton and J. C. Corey

Approved by

E. L. Albenesius, Research Manager

Environmental Effects Division

Publication Date: June 1976

E. I. DU PONT DE NEMOURS AND COMPANY SAVANNAH RIVER LABORATORY AIKEN, SOUTH CAROLINA 29801 
INTERINAL DISTRIBUTION

Copy

No.

1-3. T. B. Niland, SR

4. J. D. E11ett, Wilm

5. H. F. Ring

6. F. E. Kruesi - J. F. Proctor

7. L. C. Evans - J. W. Croach

8. W File

9. L. F. Shafxanek, Eng Dept

10. W. J. Mott $\in 1$, SRP

11. R. Maher

12. S. Mirshak

13. J. L. Womack

14. J. N. Beatty

15. D. C. Nichols - E. J. O'Rourke

16. 0. W. Mowry.

17. Q. R. Harper

18. W. P. Martin

19. R. G. Garvin

20. C. M. Patterson

21. H. A. McClearen

22. J. S. Murdock

23. R. D. Caldwell

24. R. C. Cooley

25. C. H. Ice - L. H. Meyer, SRL

26. J. L. Cranda11

27. E. L. Alberesius

28. T. V. Crawford

29. W. R. Jacotsen

30. W. L. Marter

31. W. C. Reinig

32. E. B. Sheldon

33. J. C. Corey

34. J. H. Horten, Jr.

35-59. TIS

60. TIS Record Copy 
INTERINAL DISTRIBUTION

\author{
Copy \\ No. \\ 1-3. T. B. Niland, SR \\ 4. J. D. Ellett, Wilm \\ 5. H. F. Ring \\ 6. F. E. Kruesi - J. F. Proctor \\ 7. L. C. Evans - J. W. Croach \\ 8. WFile \\ 9. L. F. Shafranek, Eng Dept \\ 10. W. J. Mott $\in 1$, SRP \\ 11. R. Maher \\ 12. S. Mirshak \\ 13. J. L. Womac:k \\ 14. J. N. Beatty \\ 15. D. C. Nichols - E. J. O'Rourke \\ 16. 0. W. Mowry \\ 17. Q. R. Harper \\ 18. W. P. Martin \\ 19. R. G. Garvin \\ 20. C. M. Patterson \\ 21. H. A. McClearen \\ 22. J. S. Murdock \\ 23. R. D. Caldwe 11 \\ 24. R. C. Cooley \\ 25. C. H. Ice - L. H. Meyer, SRL \\ 26. J. L. Crandall \\ 27. E. L. Alberesius \\ 28. T. V. Crawford \\ 29. W. R. Jacotsen \\ 30. W. L. Marte $r$ \\ 31. W. C. Reinig \\ 32. E. B. Sheldon \\ 33. J. C. Corey \\ 34. J. H. Horten, Jr. \\ 35-59. TIS \\ 60. TIS Record Copy
}


IINTERINAL DISTRIBUTIOIN

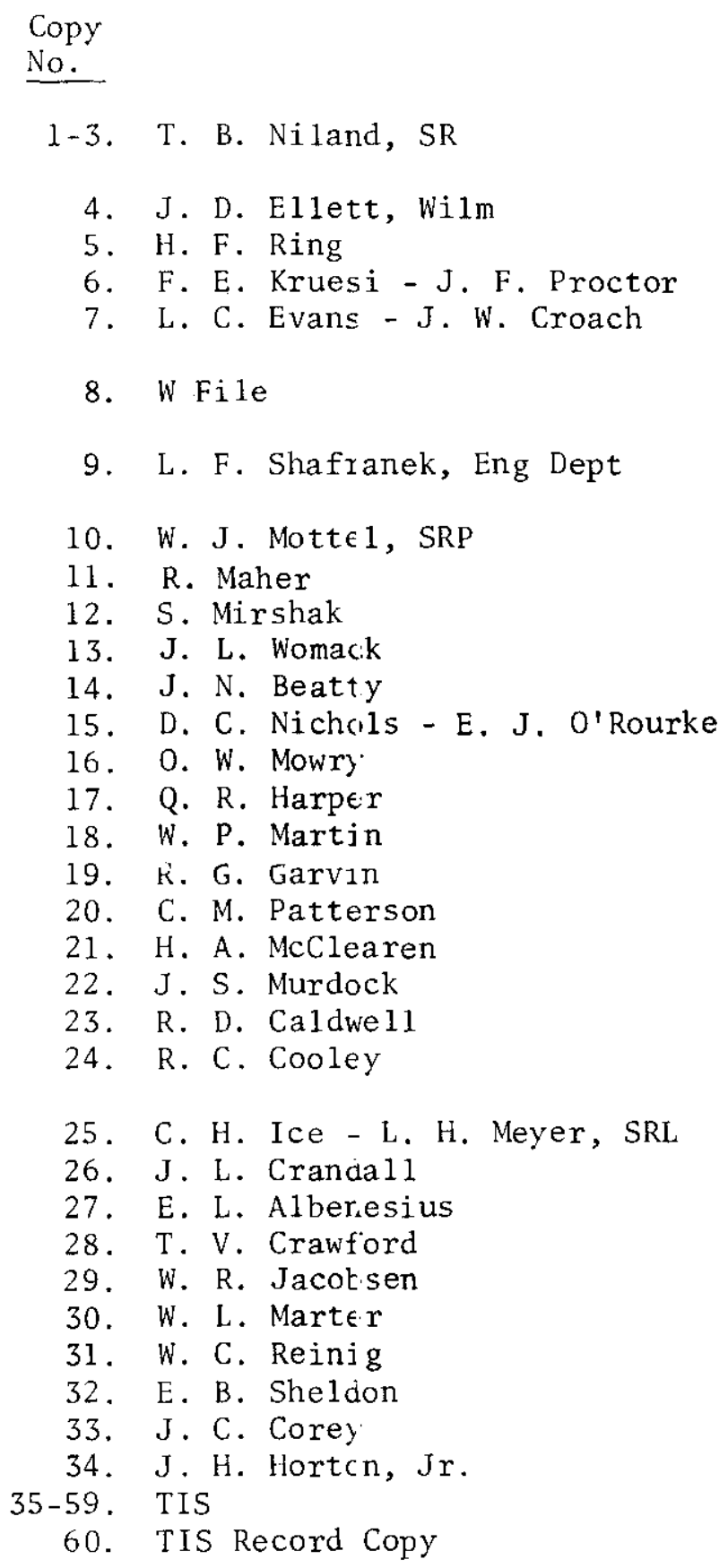


IINTERINAL DISTRIBUTION

Copy

No.

1-3. T. B. Niland, SR

4. J. D. E1lett, Wilm

5. H. F. Ring

6. F. E. Kruesi - J. F. Proctor

7. L. C. Evans - J. W. Croach

8. W File

9. L. F. Shafranek, Eng Dept

10. W. J. Mott $\epsilon 1$, SRP

11. R. Maher

12. S. Mirshak

13. J. L. Womack

14. J. N. Beatty

15. D. C. Nicho1s - E. J. O'Rourke

16. O. W. Mowry

17. Q. R. Harper

18. W. P. Martin

19. R. G. Garvin

20. C. M. Patterson

21. H. A. McClearen

22. J. S. Murdock

23. R. D. Caldwe 11

24. R. C. Cooley

25. C. H. Ice - L. H. Meyer, SRL

26. J. L. Crandall

27. E. L. Alberesius

28. T. V. Crawford

29. W. R. Jacotsen

30. W. L. Marter

31. W. C. Reinig

32. E. B. Sheldon

33. J. C. Corey

34. J. H. Hortcn, Jr.

35-59. TIS

60. TIS Record Copy 


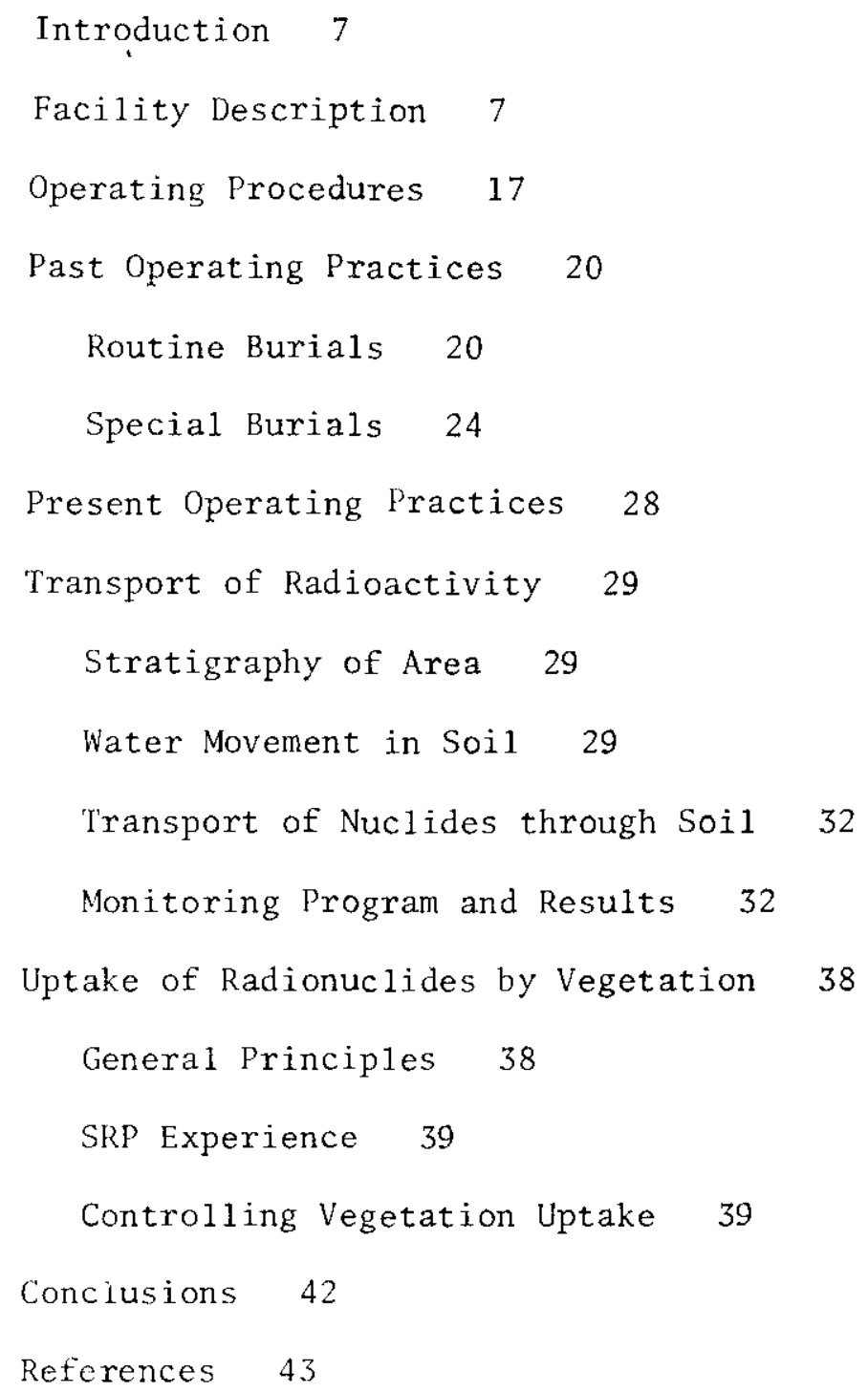


1 Solid Radioactive Waste Storage Site Location on SRP 8

2 Above Ground and Bunker Storage 11

3 Solvent Storage Facility 12

4 Sandblasting Facility 13

5 Equipment Repair Area 14

6 Building at Entrance to Solid Radioactive Waste Storage Site Containing Offices and Clothing Change Facilities 15

7 Solid Radioactive Waste Storage Site Map Showing Trenches and Grid Spacings 16

8 A Health Physics Inspector Checks the Shielded Crane for Smearable Radionuclides 17

9 Radioactive Solid Waste Record 18

10 Concrete Containers for Transuranic Waste 21

11 Concrete Encapsulation of Equipment Too Large for Concrete Containers 22

12 Transuranic Waste in Concrete Containers Being Placed in Alpha Trench 23

13 Low Level Trench Containing Boxed Paper and Laboratory Waste Being Refilled Using a Bulldozer

14 Process Pipe Burial in High Level Waste Trench 25

15 Spanish Soil Burial 
16 Hydrostatic Head in Ground Water Near Solid

Radioactive Waste Storage Site 31

17 Solid Radioactive Waste Storage Site Wells Prior to $1973 \quad 33$

18 Wells Screened at Bottom of Burial Trenches in the SRP Solid Radioactive Waste Storage Site 34

19 Water Leve1s in Backfilled Trenches 35

20 Monitoring Well Locations in Solid Radioactive Waste Storage Site in $1974 \quad 36$

21 Test plots for Evaluating Soil Covers for Burial Trenches 41

\section{LIST OF TABLES}

1 Solid Radioactive Waste Storage Site Personnel and Equipment 9

2 Radioactive Waste Burials in $1974 \quad 26$

3 Radioactive Waste Burials from Startup Through $1974 \quad 26$

4 Sediments Beneath SRP 30

5 Radionuclide Concentrations in Solid Radioactive Waste Storage Site Monitoring Wells from 1956 through 1974

6 Radionuclide Concentrations in Perched Water in the Bottom of Backfilled Trenches 35

7 Radionuclide Concentrations in Monitoring Wells (1975 Data) 37

8 Radioactivity in 1968 Vegetation 40

9 Surface Covers Currently Being Evaluated 40 


\section{INTRODUCTION}

The Savannah River Plant (SRP) occupies an approximately circular site in South Carolina of about 192,000 acres bounded on the southwest by the Savannah River and centered approximately 25 miles southeast of Augusta, Ga. Solid radioactive waste has been stored at one location at SRP since 1953. This report discusses SRP solid radioactive waste storage site facilities, describes the procedures used to segregate and the methods used to store radioactive waste materials, and summarizes monitoring results obtained from studies of the potential transport of radionuclides from buried wastes at SRP.

\section{FACILITY DESCRIPTION}

One centrally located solid radioactive waste storage site (Figure 1) is used to store all solid radioactive waste presently produced on the plant, as well as occasional special ERDA shipments from offsite. The original site of 76 acres, with 8-foot-high woven wire security fencing and lying between Road $E$ and the F-Area railroad, was filled in 1972 , and operations have shifted to a 119-acre site across the railroad tracks. The new site is partially enclosed with a similar 8-foot fence, and the remainder is enclosed with a barbed wire fence.

The solid radioactive waste storage site has a paved road to its entrance and has many secondary roads inside the fence for access to burial sites. Three railroad spurs permit trains to bring in heavy process equipment. The equipment and manpower assigned to operate the facility are listed in Table 1 .

The solid radioactive waste storage site is principally for the managed storage of solid radioactive wastes in underground trenches or on covered pads on the surface. Examples of the materials handled to date are:

- Contaminated equipment: obsolete or failed tanks, pipes, and other process equipment. 


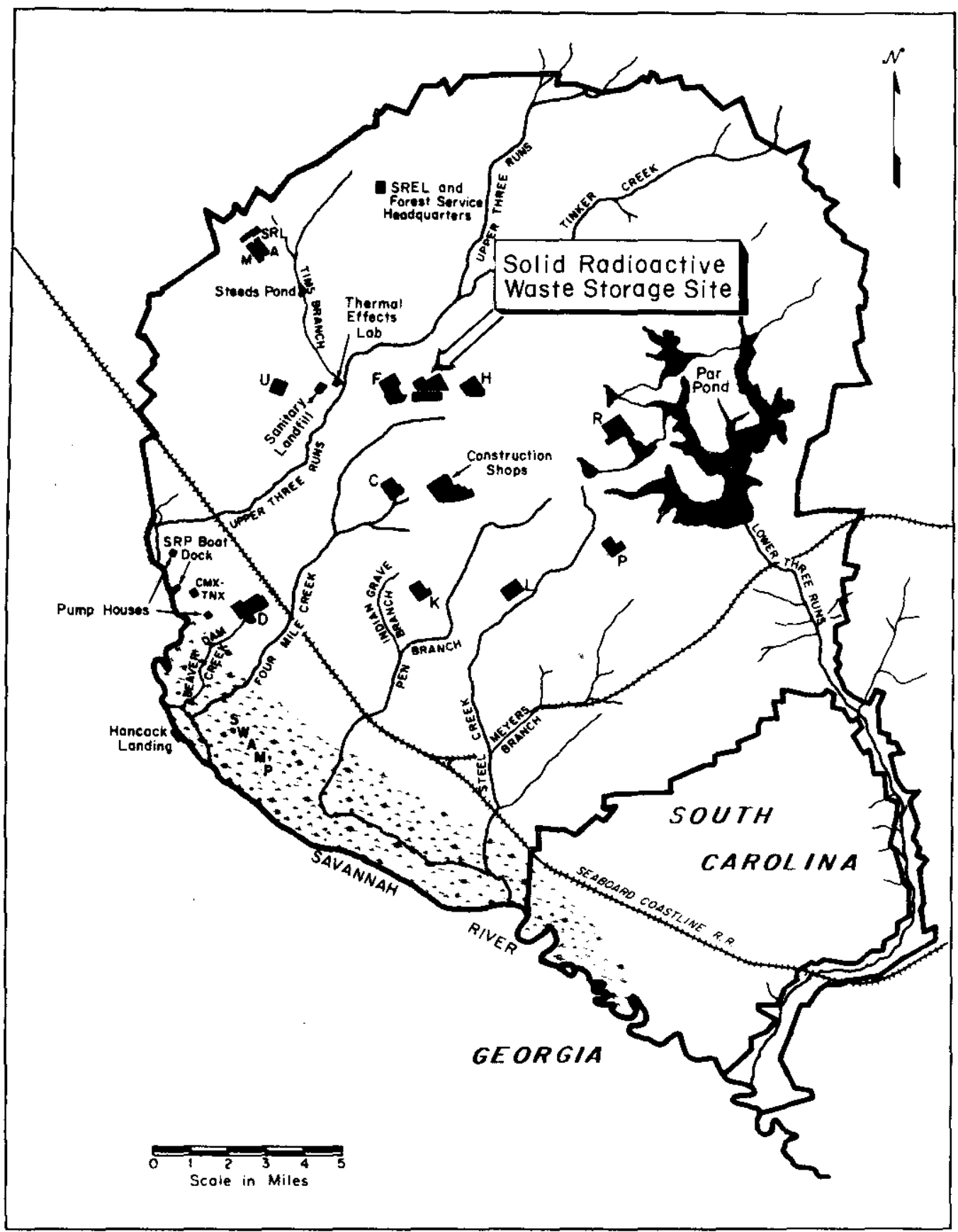

FIGURE 1. Solid Radioactive Waste Storage Site Location on SRP 


\section{TABLE 1}

Solid Radioactive Waste Storage

Site Personnel and Equipment

$\begin{array}{ll}1 & \text { Supervisor } \\ 1 & \text { Traffic and Transportation Forenan } \\ 1 & \text { Health Physics Inspector } \\ 1 & \text { Laborer } \\ 1 & \text { Heavy Equipment Operator } \\ 1 & \text { Crane Operator } \\ 2 & \text { Riggers } \\ 0.5 & \text { Dragline Operator }\end{array}$

\section{Equipment}

Shielded Crawler Crane, with a 100-foot boom and a rating of 25 tons at 35 feet extension

3-ton Mohile Hydrocrane

Dragline

Crawler Crane with Bucket for backfilling transuranium alpha waste trenches

Bulldozer for backfilling trenches

Truck with water Tank for firefighting and decontaminating recovered equipment

2 Pickup Trucks

l Carryall Truck

25-ton Fork Lift 
- Reactor and fuel hardware: fuel components and housings not containing fuel or products.

- Spent 1ithium-aluminum targets: the waste target alloy after tritium was extracted by melting the alloy.

- Oil from gas displacement pumps in the tritium facilities: prior to burial, the oil is placed in drums containing an absorbent material.

- Laboratory and operating waste: small equipment, clothes, analytical waste, decontamination residues, plastic sheeting, gloves, etc.

- Special shipments from offsite: tritiated waste from

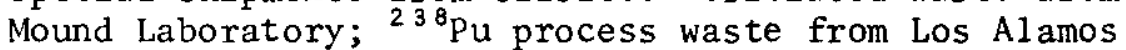
Scientific Laboratory and Mound Laboratory; debris from 2 U.S. airplane accidents in foreign countries.

- Spent deionizer resins: from reactor use.

Several facilities and operations in the area are not directly related to the burial of solid waste. These include above-ground storage of process equipment that is to be returned to service (Figure 2), an organic solvent storage facility (Figure 3 ), a sandblasting facility for decontaminating equipment (Figure 4), and an equipment repair area (Figure 5). The solid radioactive waste storage site office and clothing change facilities are shown in Figure 6.

The solid radioactive waste storage site is divided into sections for transuranium alpha waste, low-level waste, and highlevel waste (Figure 7). 

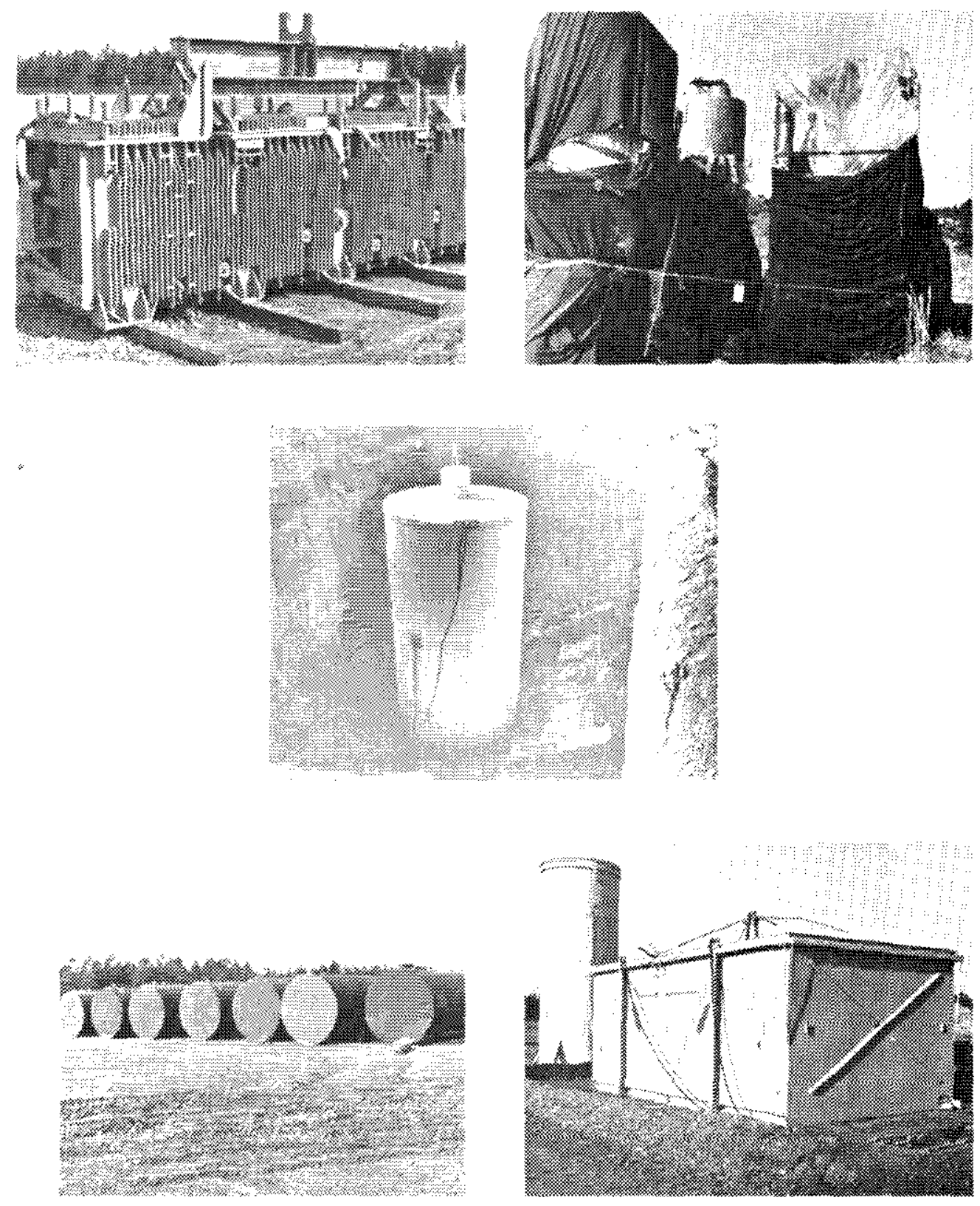

FlaveE 2. Above around and Bunker storage 


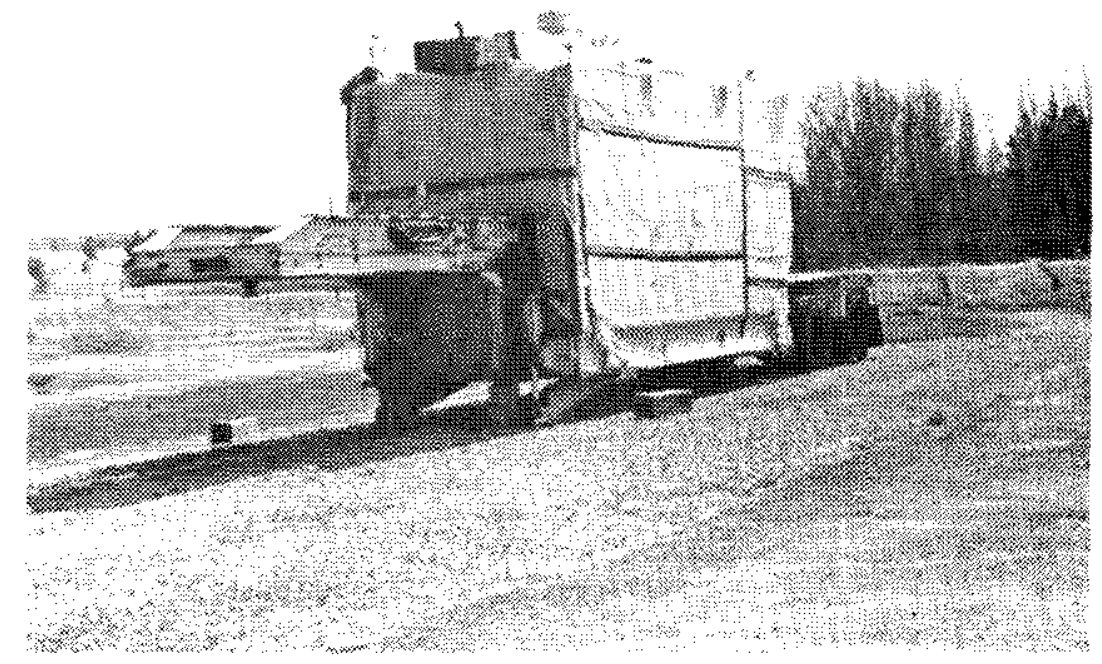

a. Solvent Trailer for Transporting Solvent from Separations Areas to Burial Ground

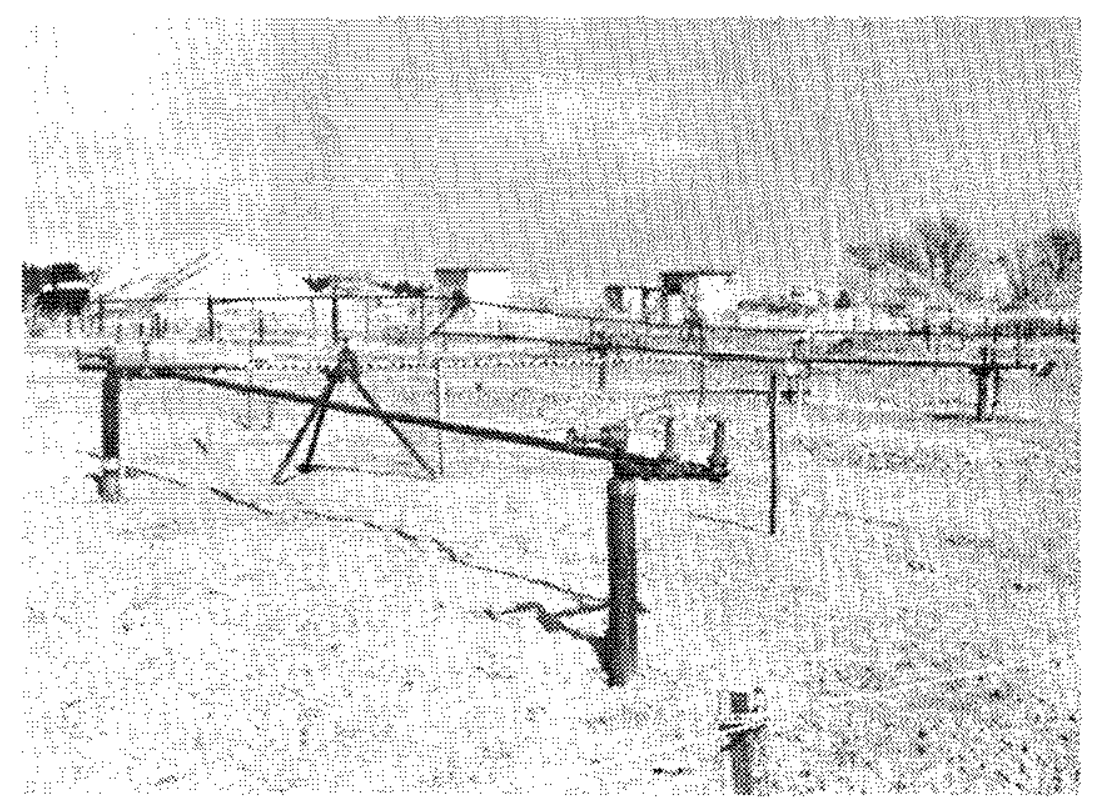

b. Underground Tank Storage Area

FIGURE 3. Solvent Storage Facility 


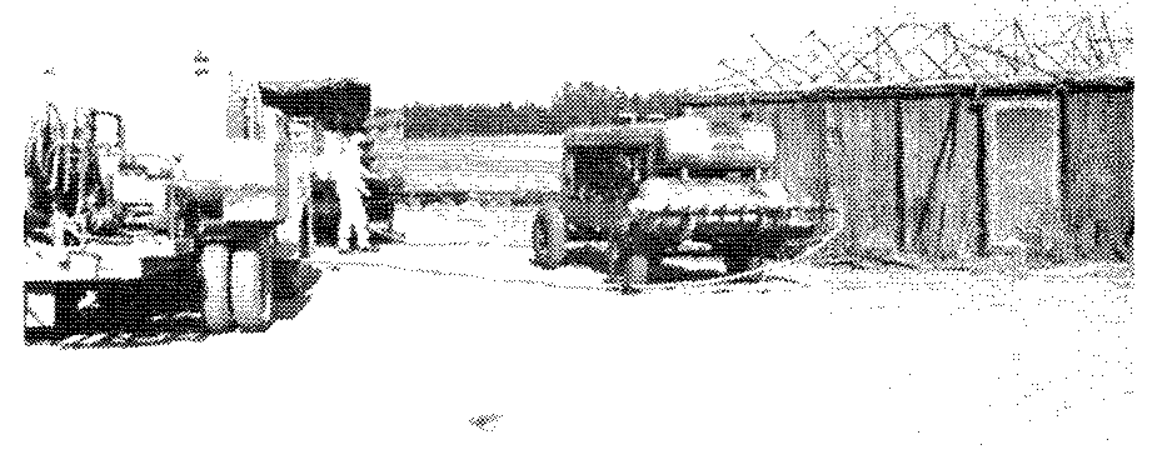

a. Exterior View

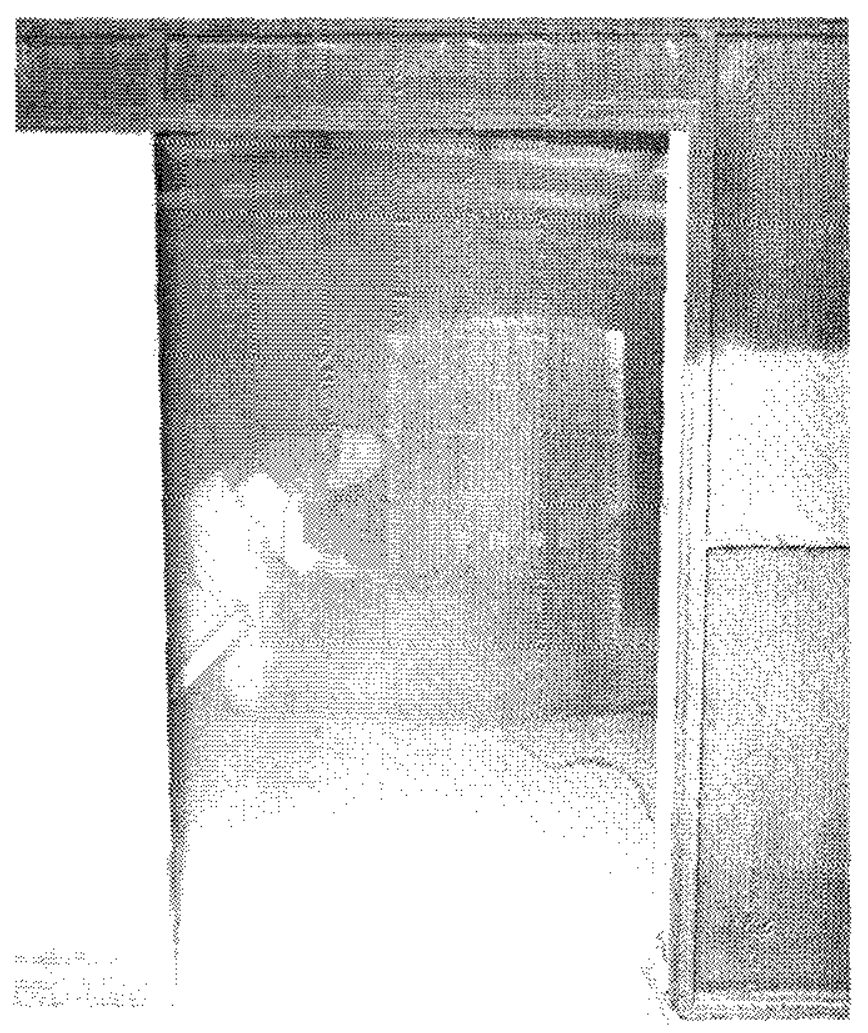

b. Interion View

FlGuRe 4. Sandblasting Facility 


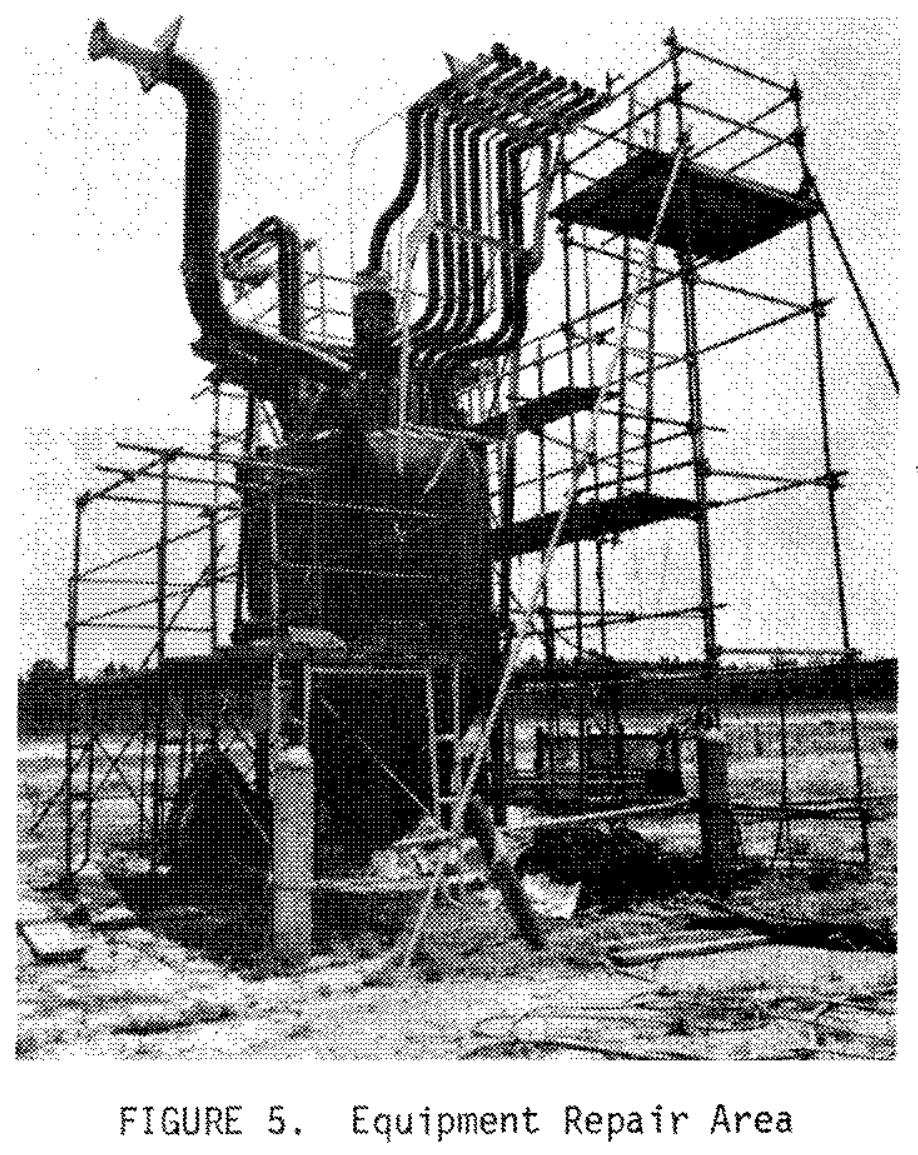




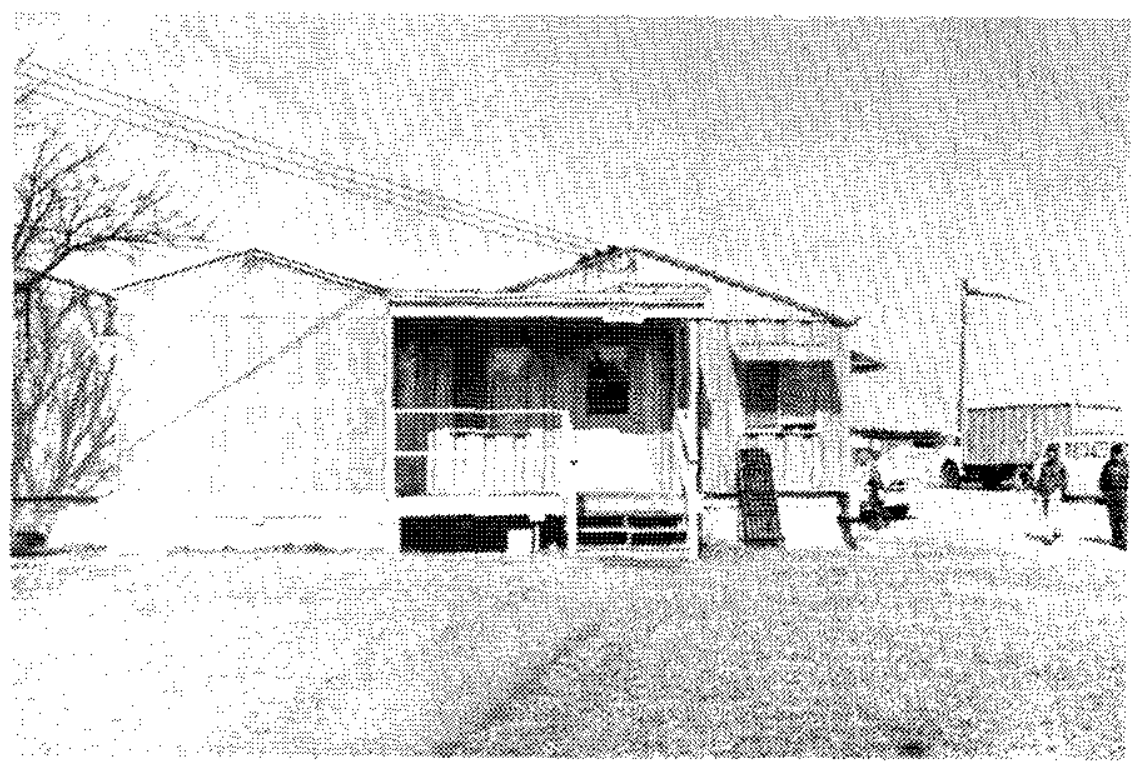

FuURE 6. Building at Entrance to Solld Radioactive Waste Storage site Containing offices and Clothing Change Facilities 


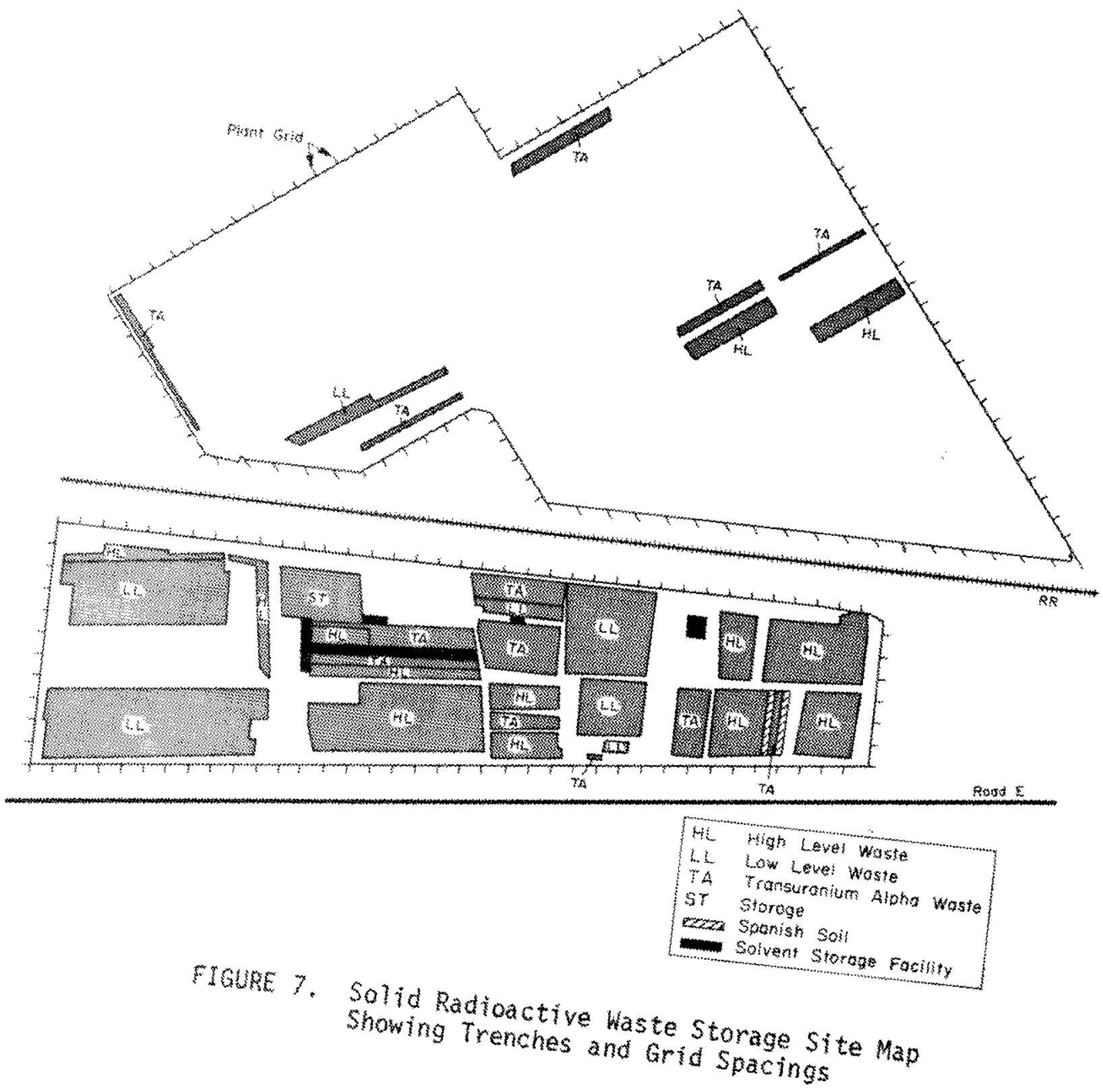




\section{OPERATUM POOCEURES}

Procedures and job plans are witten prion to initiating

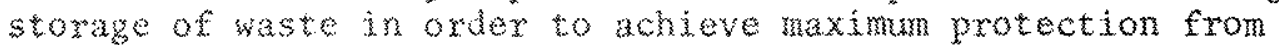

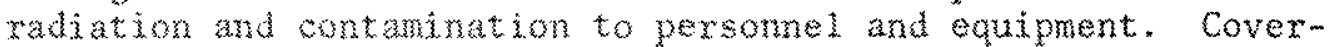
alls, zubber shoe covers, gloves, eye protection, and hard hats are requad for gersomel assisting with waste handing operam tions (figure 8 ). Only essential vehicles are permited to enter the solut radionctive waste storage site. The vehicles are surveyed for contamiation before leaving. A Health physics inspecto observes buralu of highmevel waste and makes routine sumeys so determe ground surace op vegetation contamination.

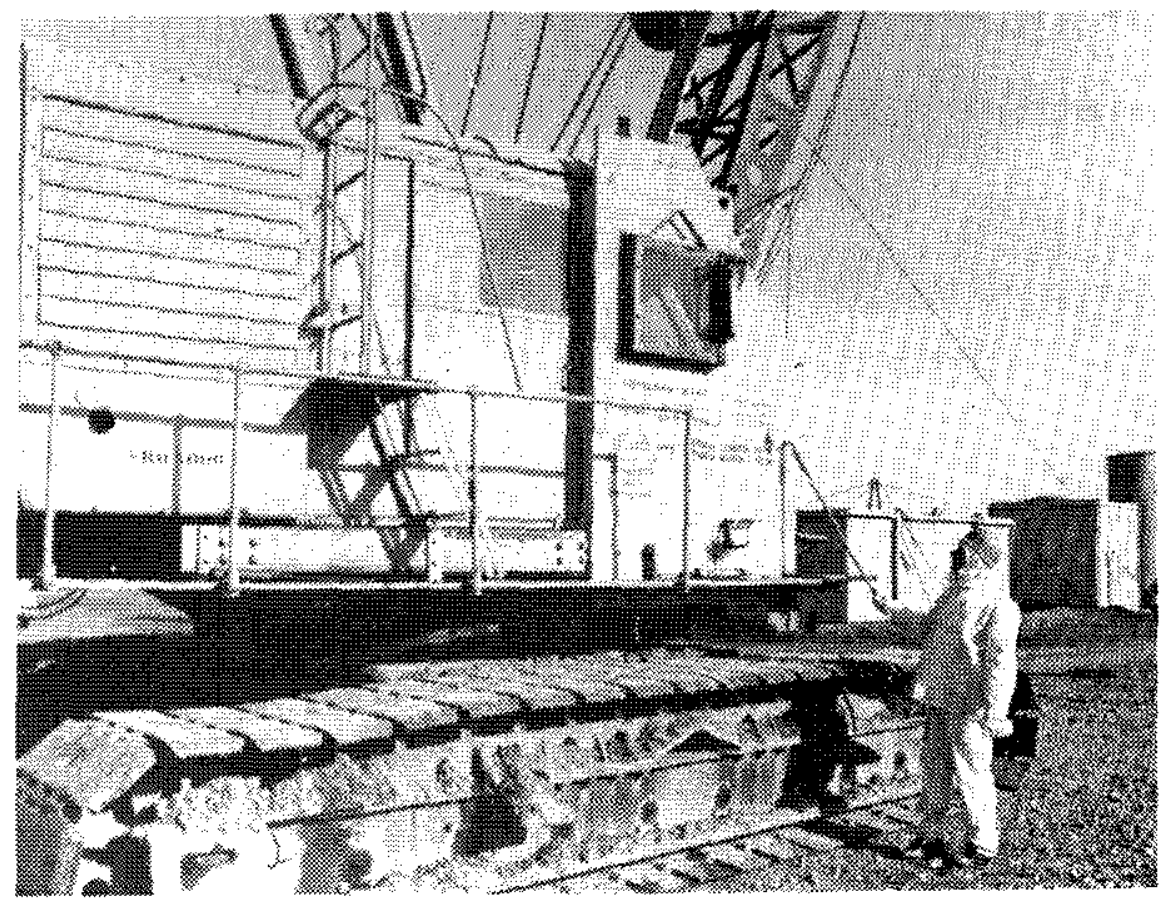

Floup 8. A Heanth Physics Inspector Checks the shielded Crane for Smearable Radionuclides

The supervisor of the sold raboactive waste storage site keeps accurate records of the contents, ratation level, and butial hocation of exch load received. Shipments are described and recorded m a Rabacherve Solid Waste Record (Figure 9), and permanent computarized records are mantained on magnetic tape. the exact location of the twenches is defined by use of a $100-$ foot grid system lald out an 1960. The 100-foot gxids are furthex divided into swentym 20 foot squares. previous to 1960 the trenches were defined with concrete makers. 


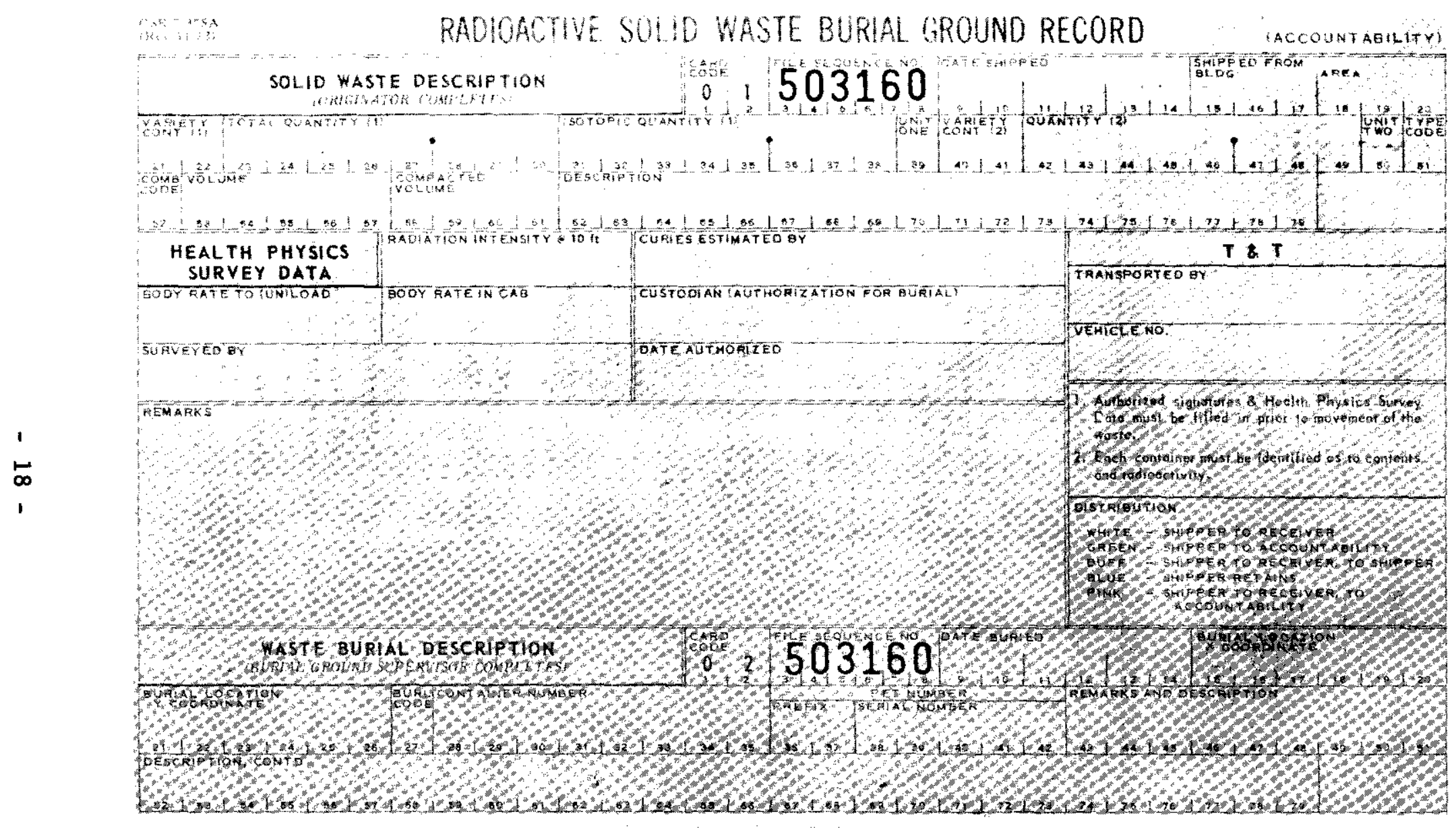

a. Obverse Face

FIGURE 9. Radioactive Solid Waste Record 


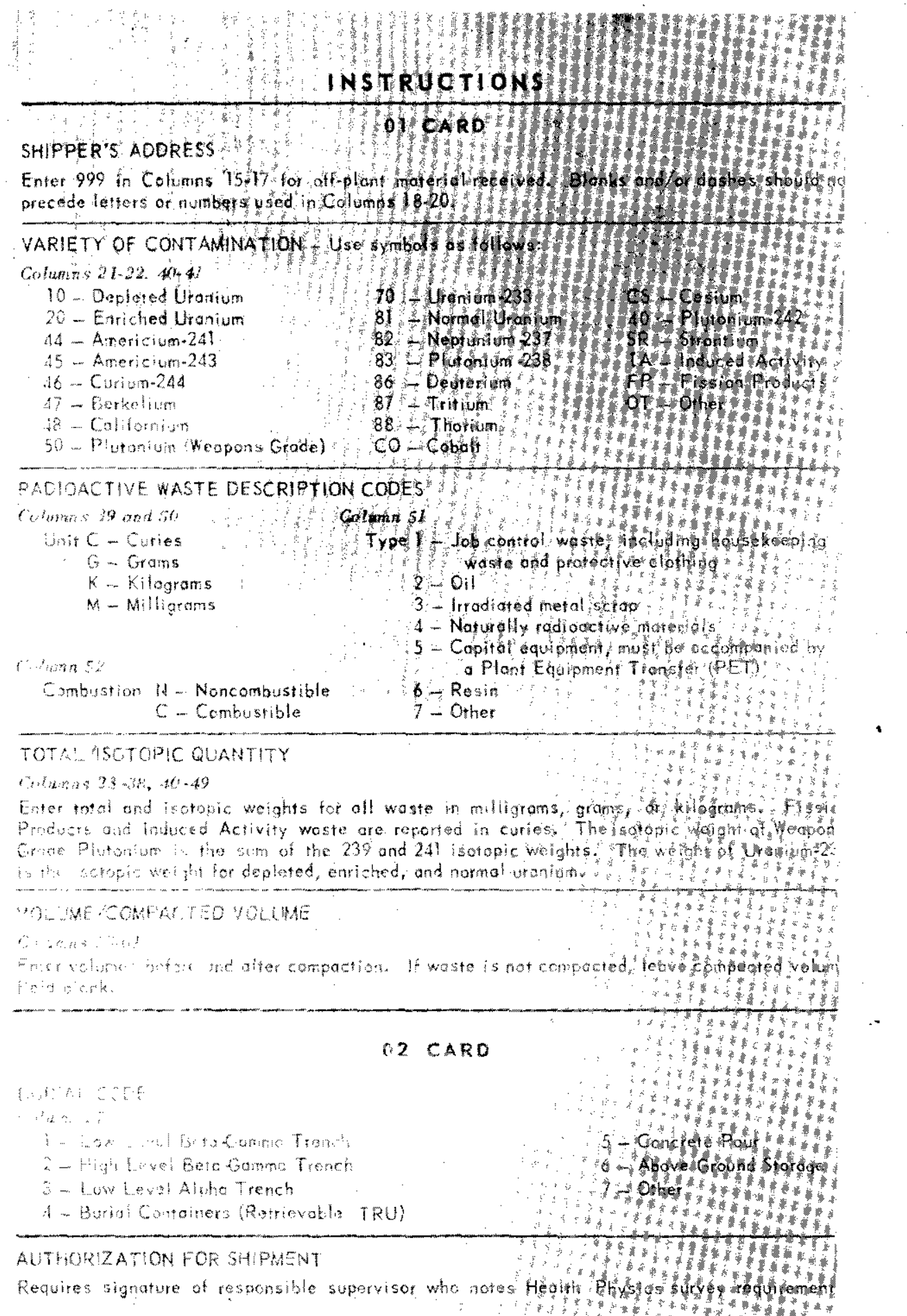

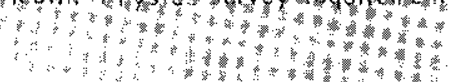

\section{Keverse race}

\section{FIGURE 9. Continued}


Burials are made in trenches that are 20 feet deep and 20 feet wide. Low-level waste is unloaded manually or emptied directly into trenches. Where the radiation dose rate is high, the waste is handled remotely. For the highest dose rates, a shielded crane is used. Waste is covered by soil soon after burial to reduce radiation, contamination, and the possibility of fire. The minimum soil cover is 4 feet, but must be sufficient to reduce surface radiation to $6 \mathrm{mR} / \mathrm{hr}$ or 1 ess.

\section{PAST OPERATING PRACTICES}

\section{Routine Burials}

Radioactive waste has always been segregated into transuranium alpha, low-level, and high-level waste categories. These are described below:

\section{Transuranium Alpha Waste}

From 1964 to 1974 this waste was segregated into, two divisions:

\section{- Retrievable}

Waste containing greater than 0.1 curie per package was placed in prefabricated concrete containers and then buried (Figure 10). These containers were 6 feet in diameter by 6.5 feet high. Waste that did not fit into the prefabricated concrete containers was encapsulated in concrete (Figure 11). Transuranium waste from the Savannah River Laboratory (SRL) was buried in square concrete containers (Figure 12). Prior to 1964, this waste was not placed into retrievable containers.

\section{- Nonretrievable}

Waste containing less than 0.1 curie per package was buried in a low-level transuranium alpha trench.

\section{Low-Level Waste}

Low-level waste (Figure 13) was defined as that measuring less than $50 \mathrm{mR} / \mathrm{hr}$ at 3 inches from an unshielded package, less than $50 \mathrm{mR} / \mathrm{hr}$ at 10 feet from the truck load, and less than $0.1 \mathrm{Ci}$ of transuranic alpha activity per package. Full shipments of waste, e.g., skip pans or closed container dumpsters with radiation intensities to $50 \mathrm{mR} / \mathrm{hr}$ at 10 feet, were disposed of in low-level waste trenches. Scrap uranium from the fuel fabrication operation was also placed in these trenches. 


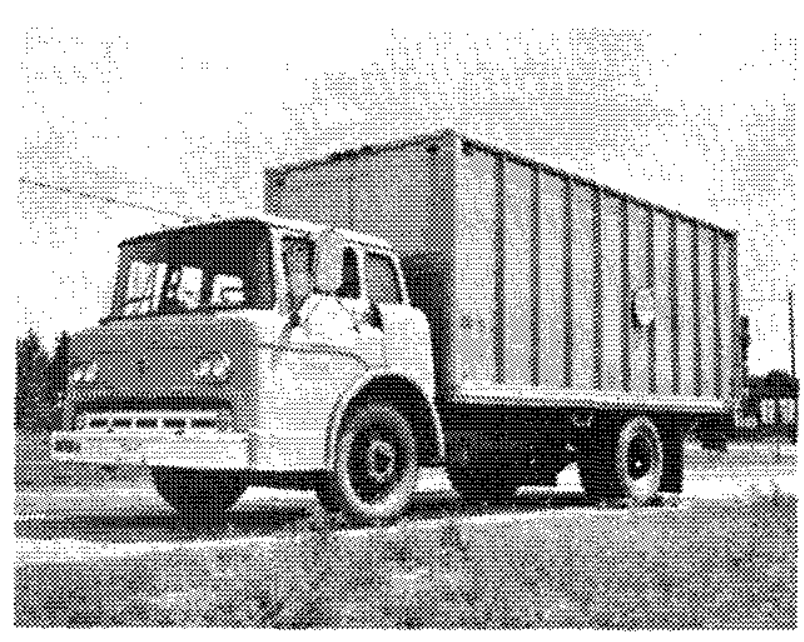

a. Transporting Vehicle

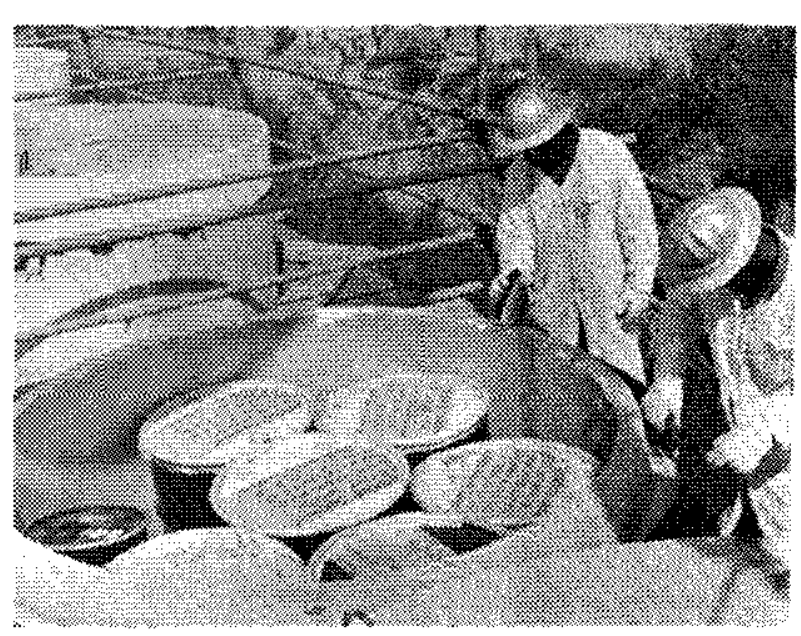

b. Interior View of Container.

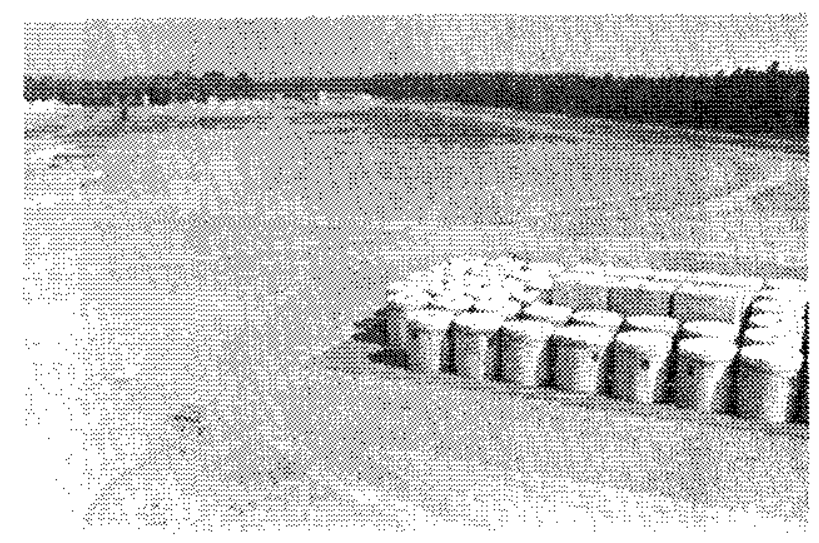

c. Assembled for Mound Burial

FIcupe 10. Concrete Containers for Transuranic Waste 


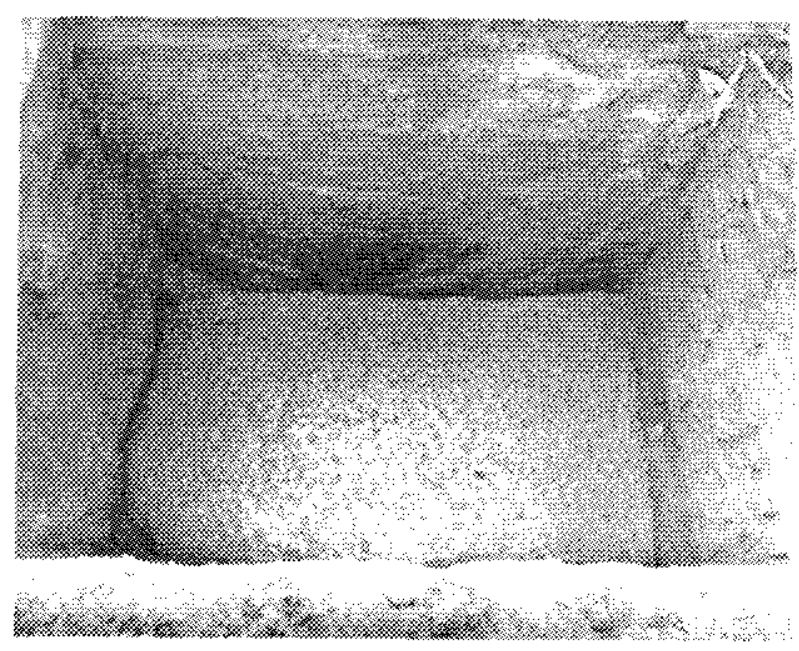

a. Concrete in Bottom of hole

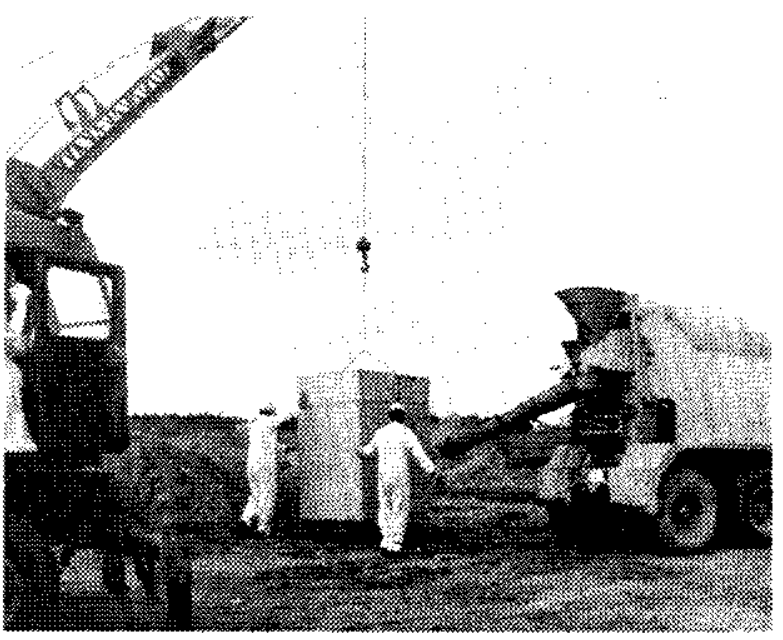

b. Placement of Equipment in Hole

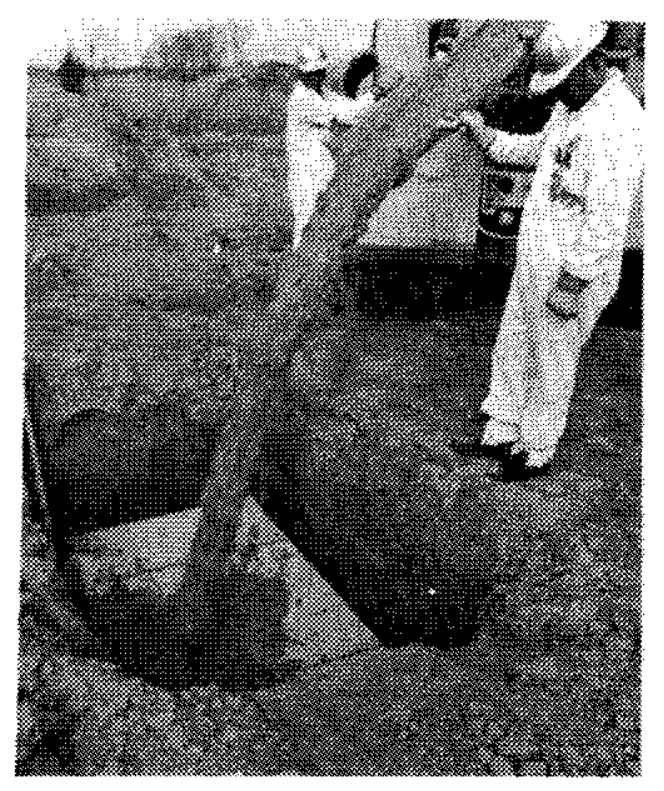

\section{c. Pouring Concrete Around Sides of Box}

FIGURE 1/. Concrete Encapsulation of Equipment too Large for Concrete Containers 


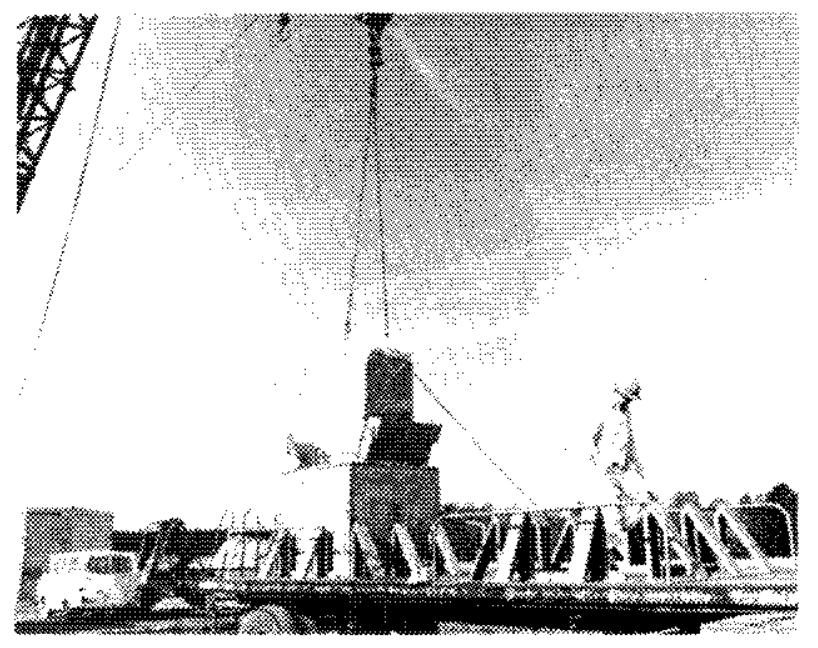

a. Transfer Cask on Trailer

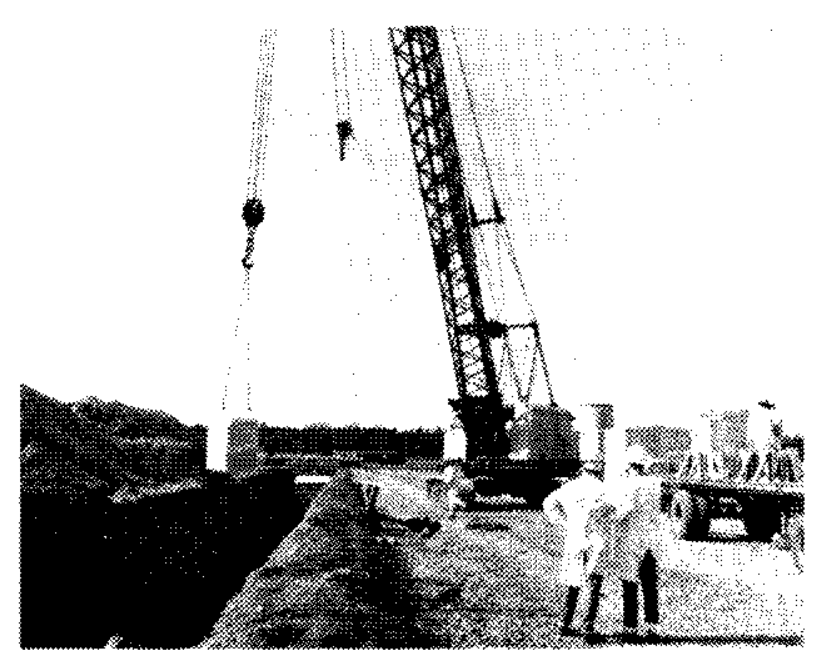

b. Concrete Box Being Placed in Trench

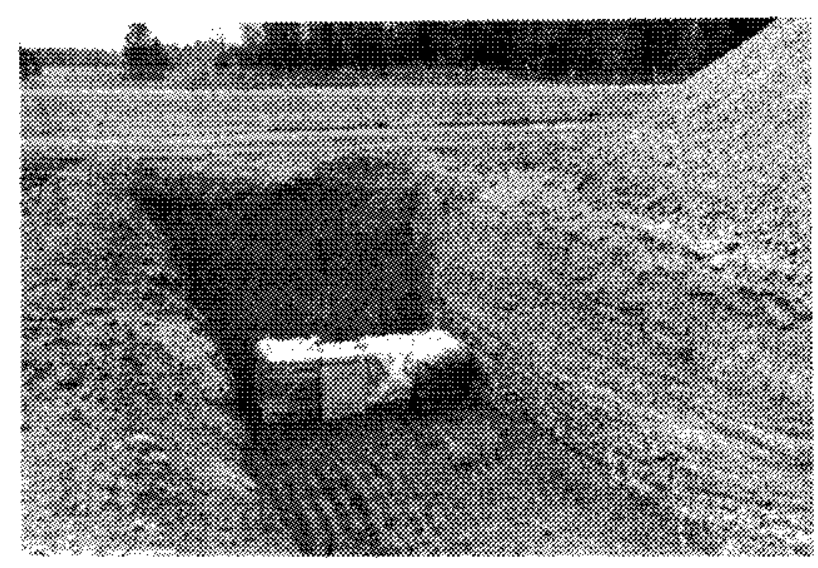

c. has te Trench

FGURE 12. Transuranic Waste in Concrete Containers Being Placed in Alpha Trench 


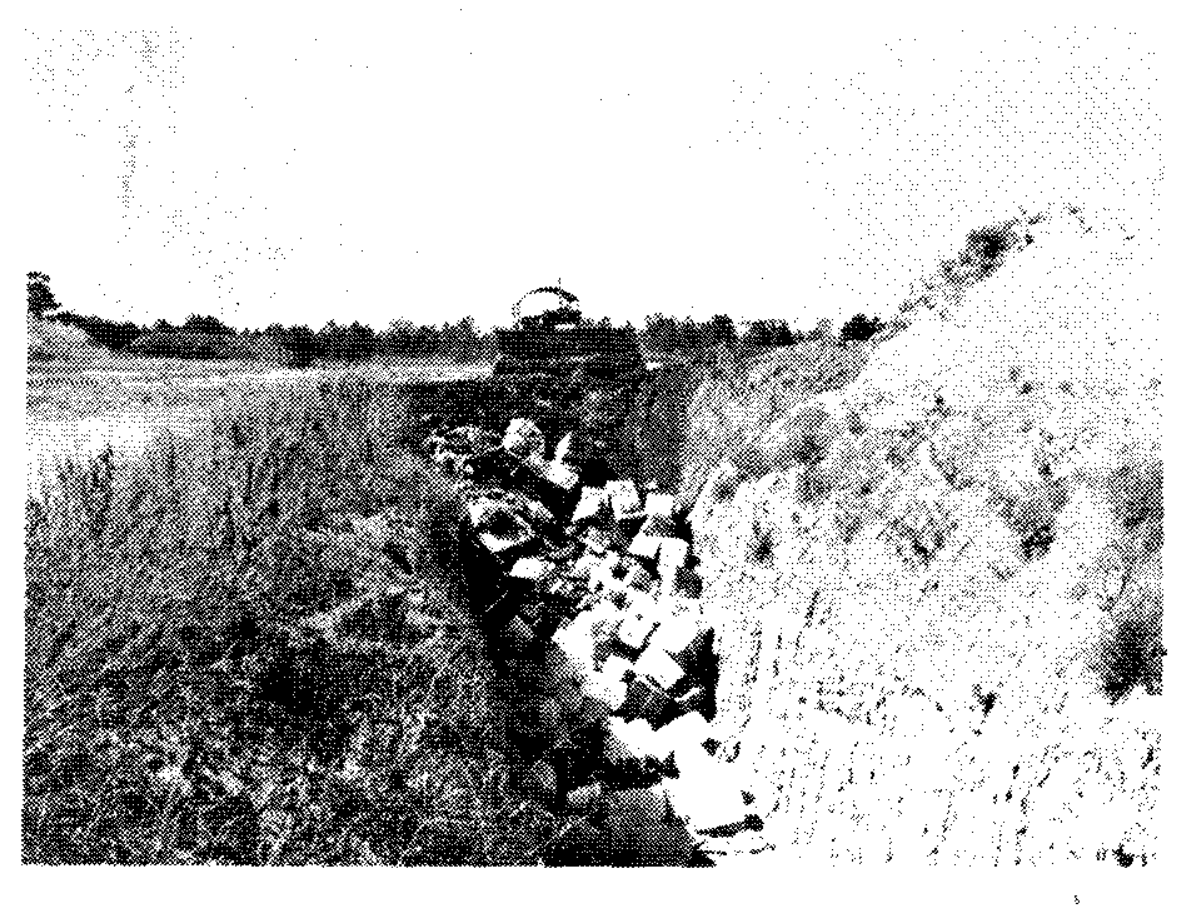

Flaurk 13. Low Level Trench Containing Boxed Paper and Laboratory Waste Being Refilled Using a Bulldozer

3. High-Level Waste

kigh-level waste was defined as that exceeding $50 \mathrm{mR} / \mathrm{hr}$ at 3 inches from an unshlelded package. An example of a typical burial operation of high-level waste is shown in Figure 1 in.

The volume and radioactivity content of waste buried in 1974 are Listed in Table 2 . The volume and radioactivity of waste buried since startup through 1974 are summarized in Table 3.

Special Burials

Occasionally shipments of classified wastes are received pex ERDA request. Two such shipments occurred following crashes of alxplanes.

a. Sparizan $50 \%$ ?

A collision during mid-ait refueling on January 17,1966 , between a bomber carrying nuclear weapons and a refueling plane contaminated the ground at palomares, Spain, with plutonium. Decontamination procedures produced 


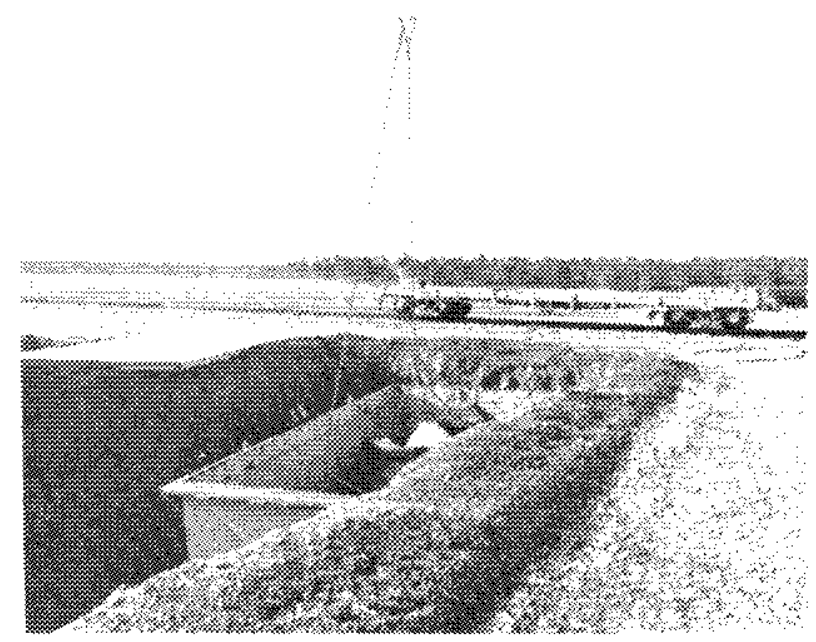

* Box Contaning process Plpe From Separations Areas in Burid Ground Trench With Lid Removed

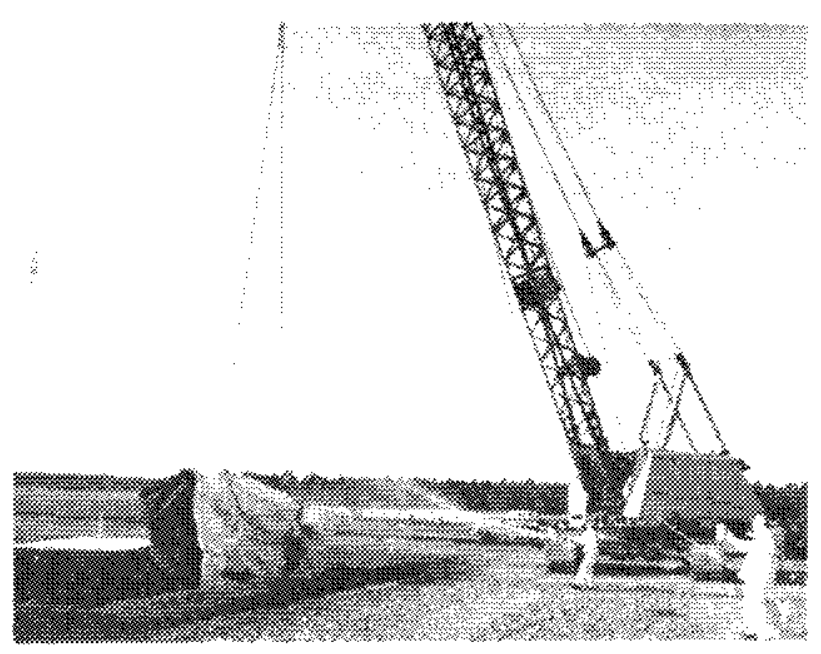

c. Removing Process Pipe From Transfer Box
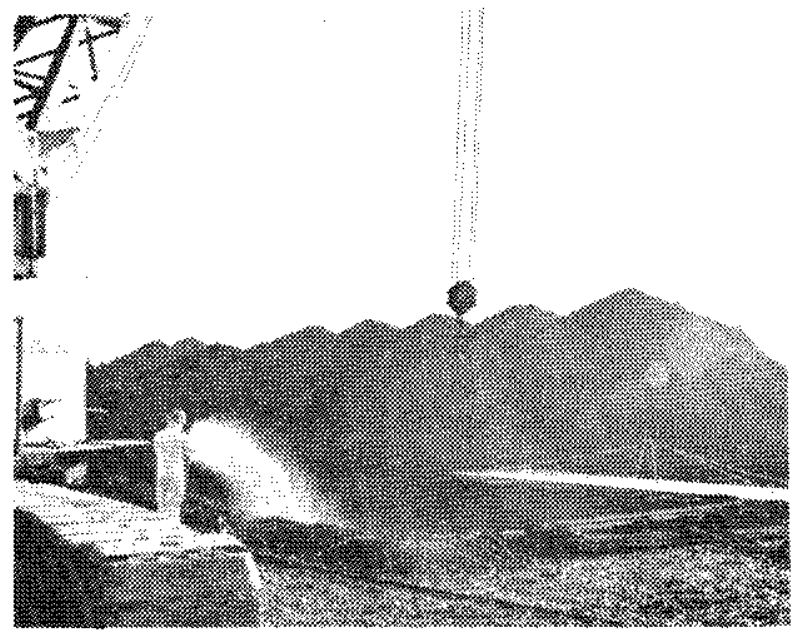

b. Spraying Box with Water to Reduce Airbome Contamination During Removal of Process Plpe From Transfer Box

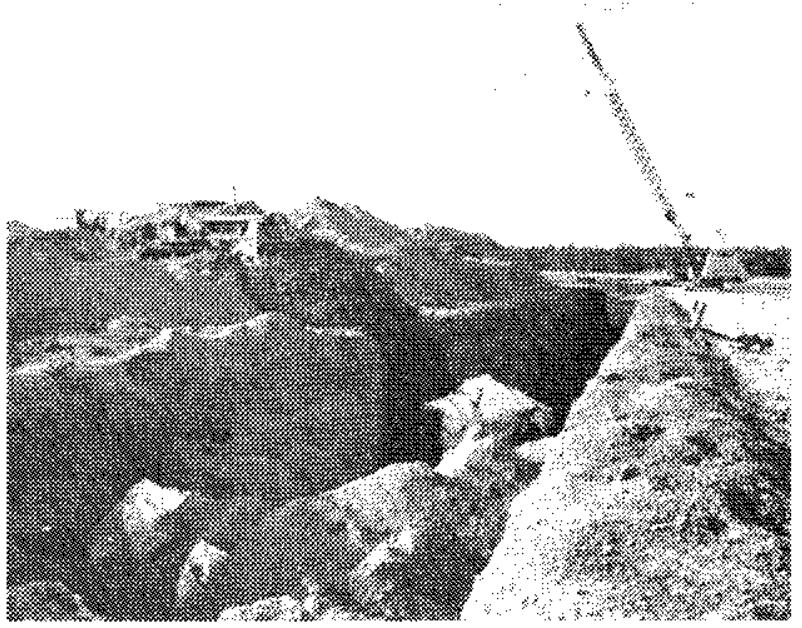

d. Covering Process Pipe With Earth

FlGuRE 14. Process Plpe Burial in High Level Waste Trench 
TABLE 2

Radioactive Waste Burials in 1974

Waste cuasezitation

$$
\begin{array}{ll}
\text { Radioativity } & \text { Volume, } \\
\text { Content, ci } & f t^{3}
\end{array}
$$

1. Transuranium Alpha Waste

Retricuable

5,000

7,000

Nonretrievable

200

74,000

2. Low Level

5,000

280,000

3. High Level

280,000

42,000

\section{TABLE 3}

\section{Radioactive Waste Burials From Startup Through 1974}

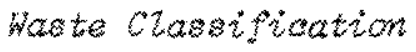

$\begin{array}{ll}\text { Radioactivity } & \text { Volume, } \\ \text { Content, ci } & f t^{3}\end{array}$

1. Transuranium Alpha Waste

Retrievable

Nonxetrievable

$$
\begin{array}{rr}
500,000 & 70,000 \\
20,000 & 1,100,000
\end{array}
$$

2. Low Level

$3,200,000$

$6,700,000$

3. Wigh Level

$4,100,000$

700,000

$4,82755-g a l l o n$ drums of soil and vegetation. These were placed in two separate trenches in 1966. The drums were buried 10 feet below the ground surface as a precaution against local infestation with plant and soll diseases from Spain (Figure 15).

b. Green Lond nee

On January 21, 1968, a bomber that carried nuclear weapons erashed in Greenland, producing large quantities of contaminated ice and aircraft parts. Recovery activities required 535 containers with a storage 


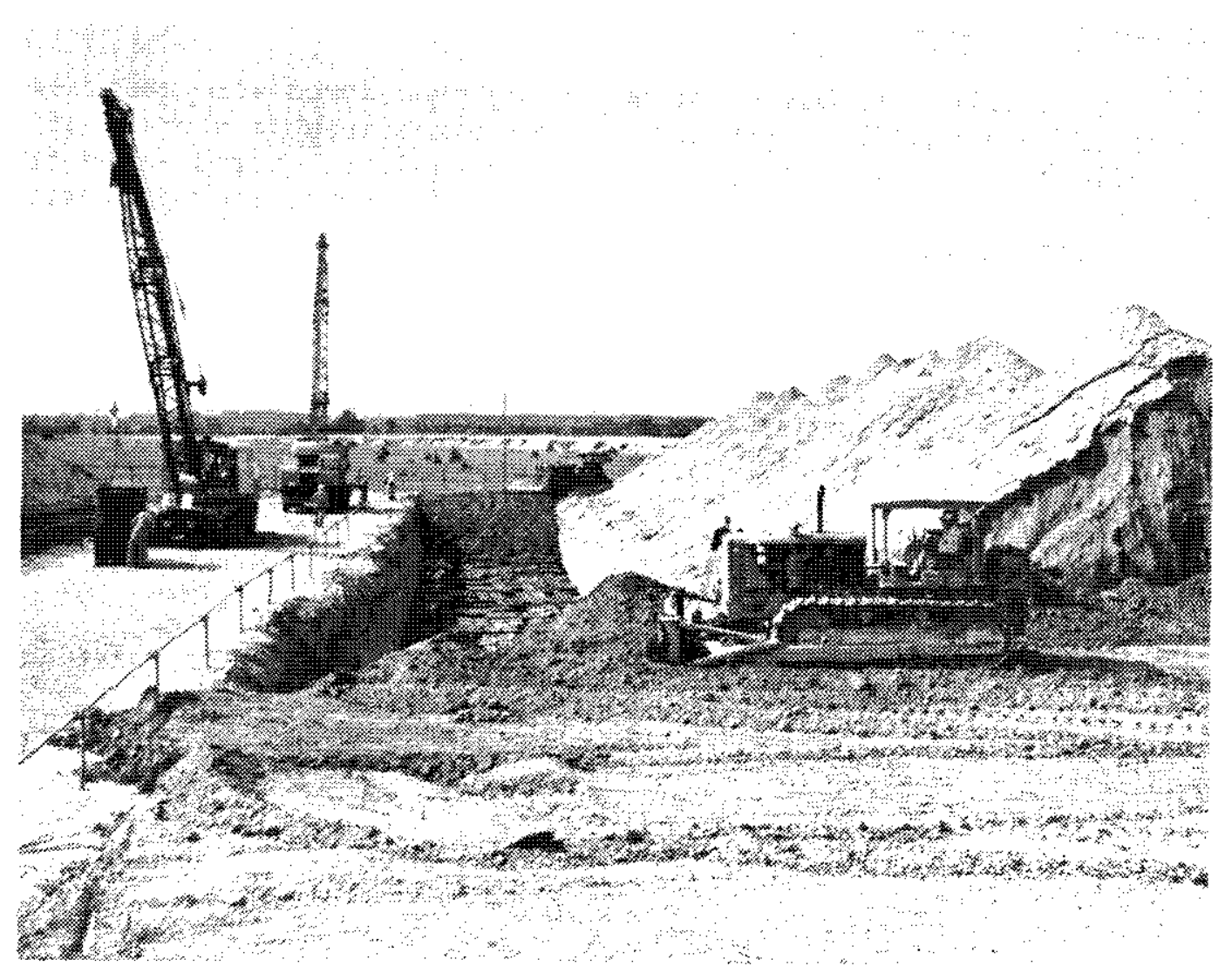

FIGURE 15. Spanish Soil Rurial

volume of 120,000 cubic feet for aircraft parts and $680,000 \mathrm{gat}$ ons of water potentially contaminated with piutonium. The water was filtered, monitored, and seat to seepage basin, except for a small fraction that was evaporated and its concentrates stored in the high level waste tamks. Aircraft parts and storage tanks have been buried in three separate trenches.

In addition to these several categories and examples of solid wate, degraded solvent is temporartiy stored in the solid radoactive waste storage site in 20 underground tanks (150,000 gal in storage in 1975$)$. The solvent contains residual transuranics and ission products that were not removable by washing procedures. Whe transuranics in 1975 totaled 456. of alpha radioactivity, primarily ${ }^{23} \mathrm{~g}_{\mathrm{y}}$ and ${ }^{23}{ }^{2} \mathrm{pu}$. Most of the fission product activity in the solvent is shortmived. A facility for incineration of this solvent inventory is being designed. 
3. The SRP limits on the quantity of beta-gamma radioactivity emplaced each year at the solid radioactive waste storage site are the following:

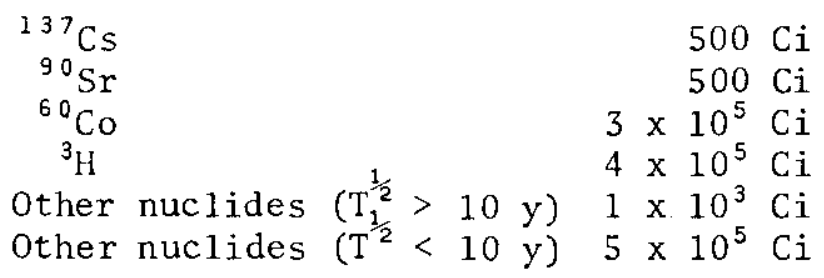

4. A comprehensive surveillance program shall be provided to monitor migration of radionuclides from their storage locations.

\section{TRANSPORT OF RADIOACTIVITY}

\section{Stratigraphy of Area}

Geological and hydrological characteristics of the SRP site favor the safe burial of radioactive solid wastes. SRP is in the Atlantic Coastal Plain physiographic province. At the solid waste storage site, the stratigraphic section consists of nearly a thousand feet of mostly unconsolidated sands, clayey sands, sandy clays, and clays (Table 4 and Reference 2). Downward flow of ground water into the prolific Tuscaloosa aquifer is prevented by a hydrostatic head reversal in the Congaree formation (Figure 16) that indicates flow is into the Congaree formation both from above and below. Thus, migration of radionuclides is confined to the direction of surface streams.

\section{Water Movement in Soil}

The highly favorable ground water hydrology compensates for the high annual rainfall, which averages $47 \mathrm{in} . / \mathrm{y} .{ }^{3}$ Because of surface runoff and evaporation, only about 15 inches flows through the soil to the water table annually; ${ }^{4}$ but this is sufficient to outweigh other mechanisms tending to move radionuclides through the soil. Therefore, migration is downward to the water table and then horizontally in the ground water to flowing surface streams. The average depth to the water table at the solid waste storage area is about 45 feet, and in the unsaturated soil above the water table, water flows at a rate of about $7 \mathrm{ft} / \mathrm{y} .{ }^{5,6}$ In the water saturated zone, water moves between 29 and $47 \mathrm{ft} / \mathrm{y}^{7}$ Because the shortest flow path from buried high level waste emplacements to Four Mile Creek is $0.5 \mathrm{mile}$, the travel time for subsurface water from the solid radioactive waste storage site to this stream is about 70 years. 
TABLE 4

Sediments Beneath SRP ${ }^{a}$

\begin{tabular}{|c|c|c|c|c|c|c|}
\hline System & Series & Formation & Lithology & $\begin{array}{c}\text { Thickness, } \\
\mathrm{ft} \\
\end{array}$ & Hydrology & $\begin{array}{l}\text { Piezometric } \\
\text { Head Below } \\
\text { Water Table } \\
\end{array}$ \\
\hline \multirow[t]{3}{*}{$\begin{array}{l}\text { Quaternary } \\
\text { to Tertiary }\end{array}$} & $\begin{array}{l}\text { Recent to } \\
\text { Pliocene }\end{array}$ & A1luvium & $\begin{array}{l}\text { Gravel, sand, } \\
\text { silt, clay }\end{array}$ & $0-30$ & $\begin{array}{l}\text { Very little } \\
\text { ground water }\end{array}$ & 0 \\
\hline & Miocene & Hawthorn & $\begin{array}{l}\text { Multicolored } \\
\text { clays, sandy } \\
\text { clays, and sands. } \\
\text { Many clastic } \\
\text { dikes }\end{array}$ & $0-80$ & $\begin{array}{l}\text { Small to } \\
\text { moderate } \\
\text { amounts of } \\
\text { ground water }\end{array}$ & 0 \\
\hline & Eocene & Barnwe 11 & $\begin{array}{l}\text { Multicolored } \\
\text { fine-coarse } \\
\text { sand and sandy } \\
\text { clay }\end{array}$ & $0-90$ & $\begin{array}{l}\text { Ground water } \\
\text { sufficient for } \\
\text { home use }\end{array}$ & 0 \\
\hline \multirow[t]{2}{*}{ Tertiary } & Eocene & McBean & $\begin{array}{l}\text { Multicolored } \\
\text { fine-coarse } \\
\text { glauconitic sand } \\
\text { and clay. Cal- } \\
\text { careous zone } \\
0-80 \mathrm{ft} \text { thick, } \\
\text { composed of lime- } \\
\text { stone, marl, clay, } \\
\text { and silicified } \\
\text { shells }\end{array}$ & $0-150$ & $\begin{array}{l}\text { Ground water } \\
\text { supply moder- } \\
\text { ate to large } \\
\text { in sandy } \\
\text { portion; smal1 } \\
\text { in calcareous } \\
\text { zone. }\end{array}$ & $\begin{array}{l}\text { Ranges from } \\
2-33 \mathrm{ft} \text { in } \\
\text { Separations } \\
\text { Areas }\end{array}$ \\
\hline & Eocene & Congaree & $\begin{array}{l}\text { Green sandy clay, } \\
\text { silt, and thin } \\
\text { hard sandstone and } \\
\text { chert beds near } \\
\text { top. Brown and } \\
\text { green sandy clay, } \\
\text { sand and silicified } \\
\text { shells below }\end{array}$ & $0-100$ & $\begin{array}{l}\text { Ground water } \\
\text { supply low to } \\
\text { moderate }\end{array}$ & $\begin{array}{l}\text { Ranges from } \\
58-102 \text { ft in } \\
\text { Separations } \\
\text { Areas }\end{array}$ \\
\hline \multirow[t]{2}{*}{$\begin{array}{l}\text { Upper } \\
\text { Cretaceous }\end{array}$} & & E1lenton & $\begin{array}{l}\text { Dark gray to black } \\
\text { sandy micaceous } \\
\text { clay, sand and } \\
\text { gypsum }\end{array}$ & $0-100$ & $\begin{array}{l}\text { Ground water } \\
\text { supply } \\
\text { moderate }\end{array}$ & $\begin{array}{l}\text { Same as } \\
\text { Tuscaloosa }\end{array}$ \\
\hline & & Tuscaloosa & $\begin{array}{l}\text { Tan, buff, red, } \\
\text { white cross-bedded } \\
\text { coarse micaceous } \\
\text { sand, clayey sand, } \\
\text { and interbedded } \\
\text { with red, brown, } \\
\text { purple clay and } \\
\text { white Kaolin }\end{array}$ & $0-600$ & $\begin{array}{l}\text { Large supplies } \\
\text { of soft ground } \\
\text { water. Yields } \\
\text { up to } 2000 \text { gpm } \\
\text { from } 8 \text { to } 12- \\
\text { inch grave } 1 \\
\text { packed wells. }\end{array}$ & $\begin{array}{l}\text { Ranges from } \\
26-91 \text { ft in } \\
\text { Separations } \\
\text { Areas }\end{array}$ \\
\hline
\end{tabular}

a. Modified from Table 2, p 16 in Siple ${ }^{2}$ 


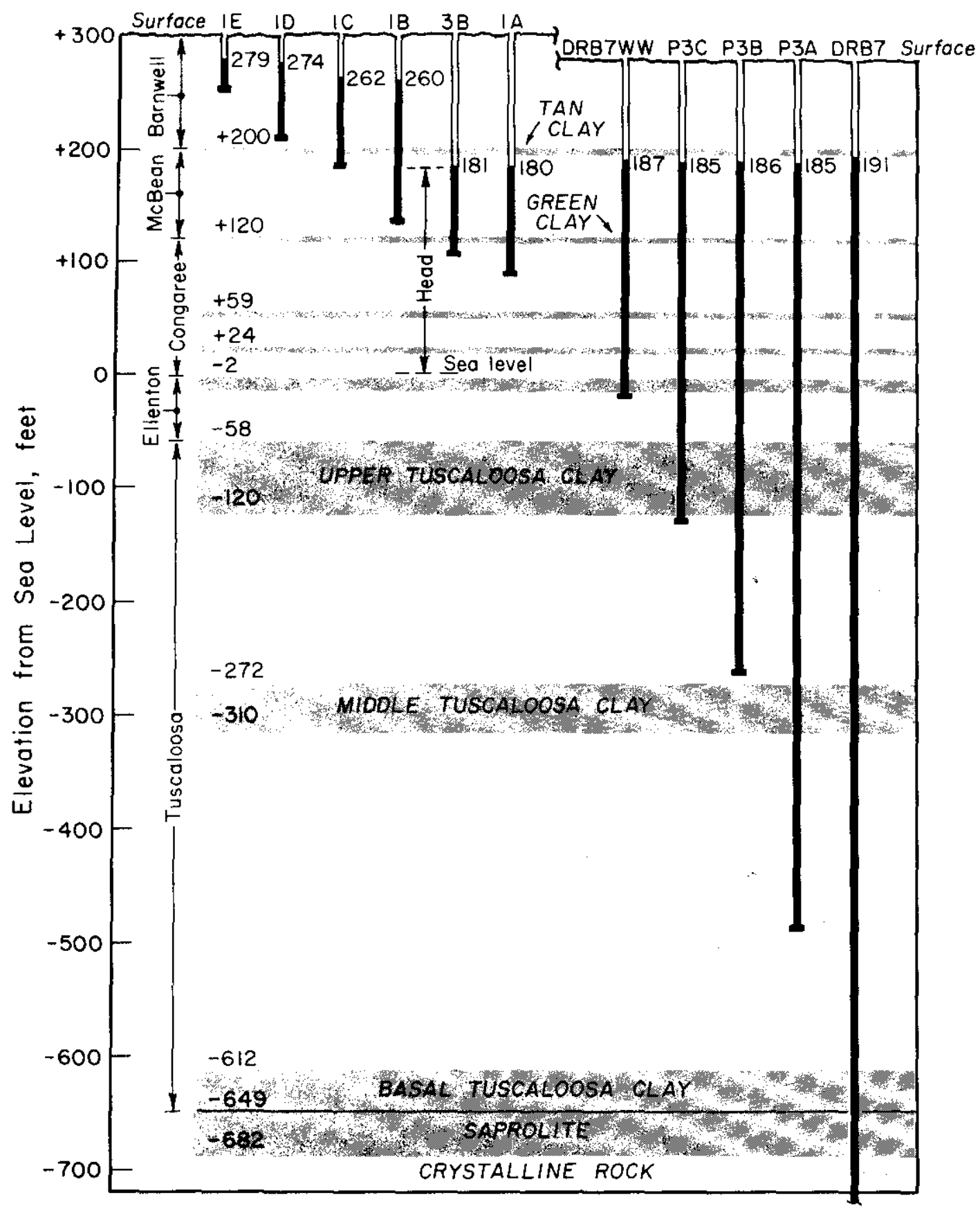

FIGURE 16. Hydrostatic Head in Ground Water Near Solid Radioactive Waste Storage Site 
Transport of Nuclides through Soil

Ion exchange will increase the travel time for strontium by a factor of 16 and cesium by a factor of $200{ }^{8}$ Thus, before emerging into Four Mile Creek, the ${ }^{90} \mathrm{Sr}$ and ${ }^{1{ }^{37} \mathrm{Cs}}$ will have decayed to much less than 1 percent of the quantity placed into the ground.

Leaching of radionuclides from buried waste is minimized by the characteristics of water in unsaturated soil. Unless all soil pores are filled with water, the soil is unsaturated and the hydrostatic pressure is less than atmospheric. Under these conditions, water will not flow from water-filled pores to airfilled pores or into cavities in the soil. Many of the radionuclides are in cavities such as the interior of pipes or vessels. In such locations, radionuclides can only be leached if the waste is in perched ground water, i.e., water-saturated soil above the permanent water table. Because of the higher water permeability in backfilled than undisturbed soil, perched water does occur in the bottom of some trenches. Monitoring data from wells installed in backfilled trenches indicate only a small quantity (tens of millicuries) of radioactivity is present in the perched water.

\section{Monitoring Program and Results}

Monitoring for radionuclide leaching through the soil in the solid waste storage area began with the installation of 9 wells in 1956 (Figure 17). Two other we1ls, BG 12 and BG 18, were installed in 1962 after the direction of ground water flow was known to be in a southwesterly direction. Well BG 8 was destroyed in the construction of new waste trenches in 1965, and Well BG 5 was similarly damaged in 1968. The concentrations of alpha and non-volatile beta-emitting radionuclides measured in these 11 wells from 1956 through 1974 were at or near background levels. Tritium concentrations are similar to those found elsewhere in the vicinity of the chemical separations areas and are due to atmospheric releases. The maximum and average concentrations measured in the wells are summarized in Table 5.

To evaluate the extent and effect of perched water in the bottom of backfilled trenches, 24 wells were installed with 6 -in.long screens at the bottom of the trenches in 1969. The locations of the wells are shown in Figure 18. Weekly water-leve1 measurements were made in these from August 1969 through July 1970. Only We11s $6,7,17$, and 19 had more than a trace of water (Figure 19). Water from these wells has been analyzed for radioactivity every 


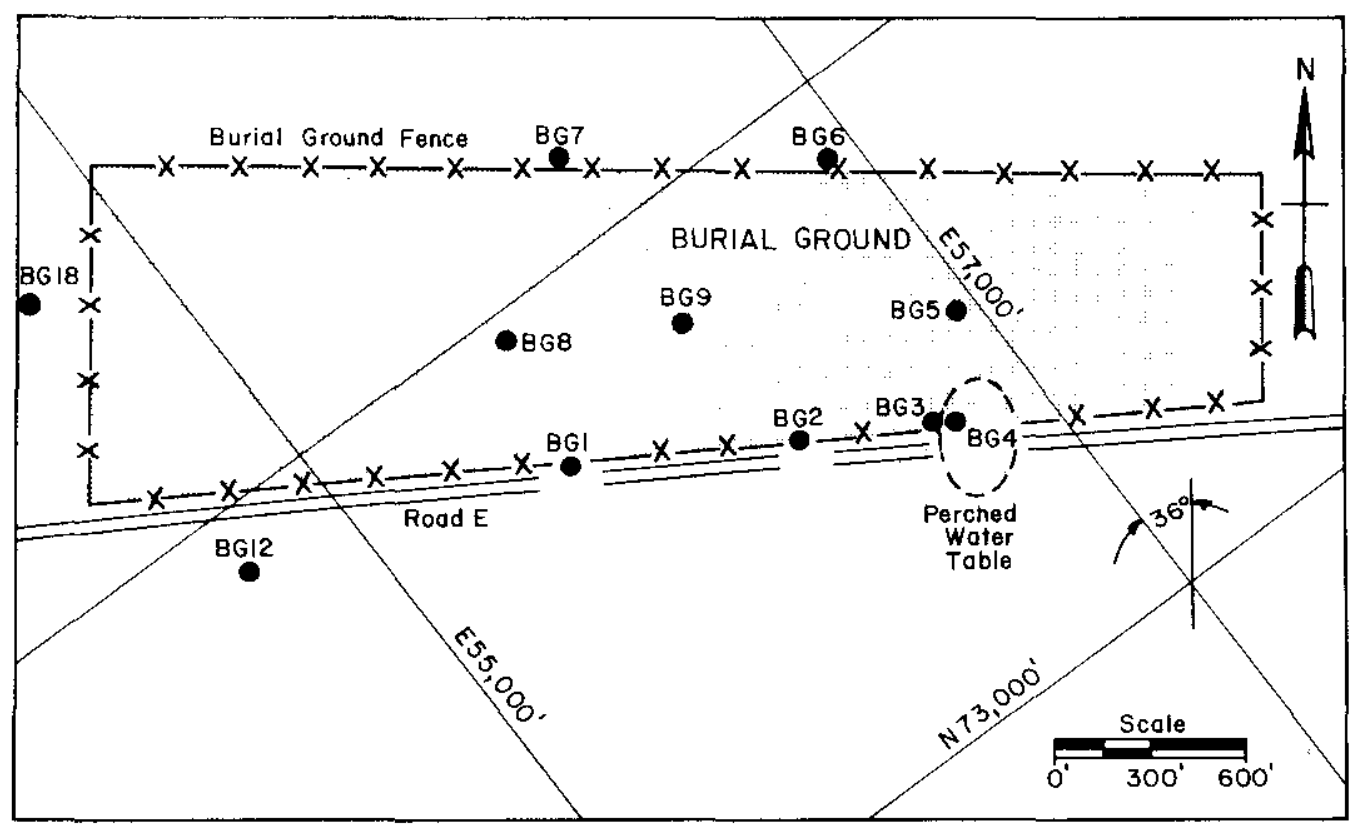

FIGURE 17. Solid Radioactive Waste Storage Site Wells Prior to 1973

TABLE 5

Radionuclide Concentrations in Solid Radioactive Waste Storage Site Monitoring Wells from 1956 Through 1974

\begin{tabular}{|c|c|c|c|c|c|c|}
\hline \multirow[b]{3}{*}{ We 22 No. } & \multicolumn{2}{|c|}{ Concentration, } & \multicolumn{4}{|c|}{$p C i /$ liter } \\
\hline & \multicolumn{2}{|l|}{ Alpha } & \multicolumn{2}{|c|}{$\begin{array}{l}\text { Nonvolatile } \\
\text { Beta }\end{array}$} & \multicolumn{2}{|l|}{ Tritium } \\
\hline & $\overline{\operatorname{Max}}{ }^{\alpha}$ & Avg. & $\overline{M a x .} .^{a}$ & Avg. & $\overline{\operatorname{Max}} .^{\alpha}$ & Avg. \\
\hline BG 1 & 0.9 & 0.5 & 13 & 7 & 62,000 & 24,000 \\
\hline BG 2 & 0.7 & 0.4 & 11 & 8 & 140,000 & 49,000 \\
\hline BG 3 & 1.4 & 0.7 & 27 & 12 & 103,000 & 58,000 \\
\hline BG 4 & 1.8 & 1.0 & 13 & 10 & 860,000 & 187,000 \\
\hline BG $5^{b}$ & 0.7 & 0.5 & 13 & 9 & 261,000 & 109,000 \\
\hline BG 6 & 0.8 & 0.4 & 77 & 13 & 87,000 & 46,000 \\
\hline BG 7 & 0.9 & 0.5 & 40 & 12 & 62,000 & 32,000 \\
\hline $\mathrm{BG} 8^{b}$ & 1.1 & 1.0 & 15 & 11 & 33,000 & 19,000 \\
\hline BG 9 & 1.5 & 0.6 & 16 & 9 & 142,000 & 42,000 \\
\hline BG $12^{b}$ & 2.0 & 1.3 & 20 & 12 & 84,000 & 35,000 \\
\hline BG $18^{b}$ & 3.6 & 1.6 & 44 & 20 & 61,000 & 37,000 \\
\hline
\end{tabular}

a. Maximum yearly average.

b. Well BG 8 was destroyed in 1965, well BG 5 was destroyed in 1968, and Wells BG 12 and BG 18 were installed in 1962 . 


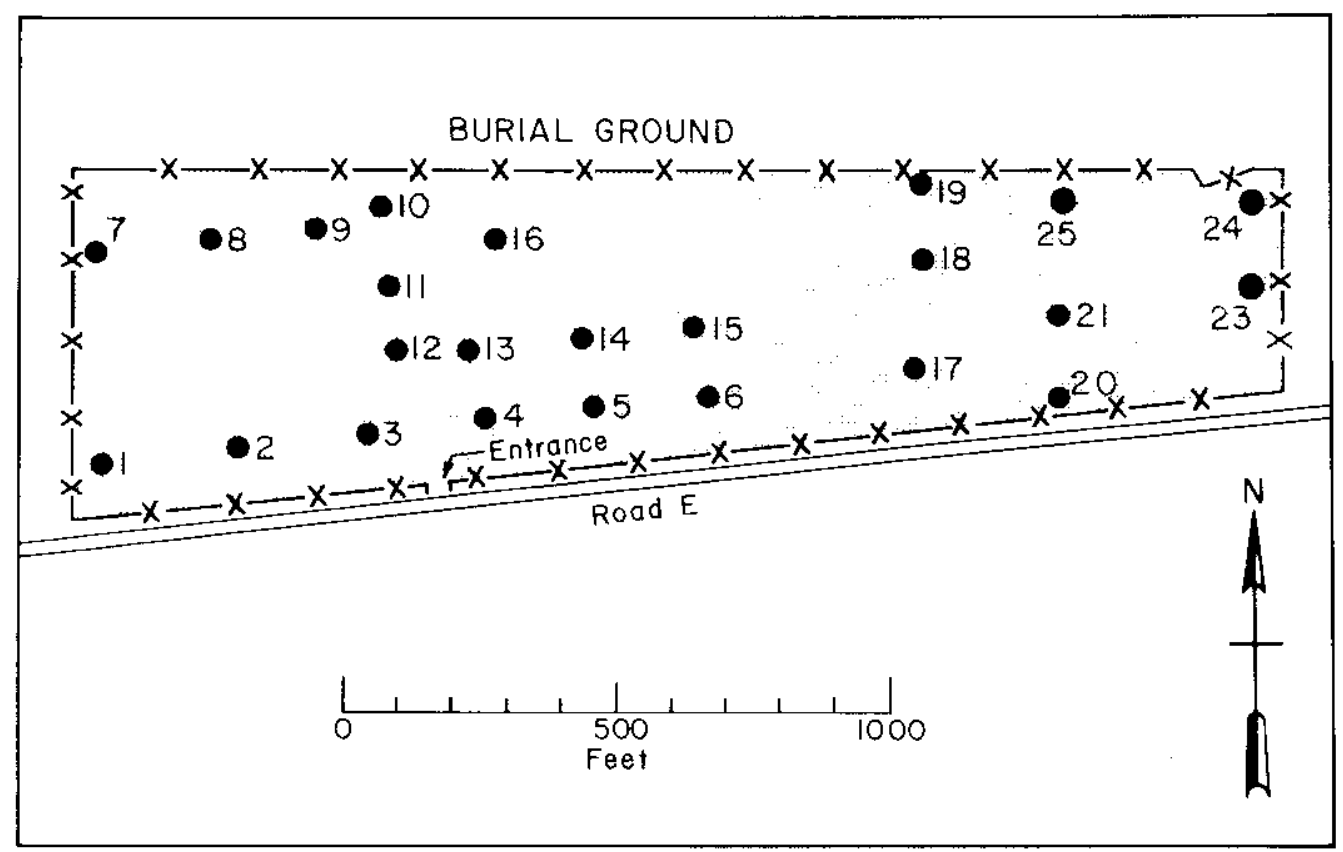

FIGURE 18. We11s Screened at Bottom of Burial Trenches in the SRP Solid Radioactive Waste Storage Site

two weeks since March 1970 . The results (Table 6) show that the waters contain levels of nonvolatile beta-emitters above background levels. During April 1974, specific radionuclide analyses showed that ${ }^{90} \mathrm{Sr}$ was the primary component of the nonvolatile beta-emitters, and ${ }^{137} \mathrm{Cs}$ and ${ }^{60} \mathrm{Co}$ were also detectable in We11 9.

When most solid waste storage operations had shifted from the original 76 -acre site in 1972 , ground water monitoring was increased by installing monitoring wells in a grid pattern on 200-foot centers (Figure 20). The predominant radioactive isotope in the monitoring data (Table 7) is tritium from the burial of spent lithium-aluminum target melts. Approximately one-third of the wells contain tritium levels significantly above concentations recorded for rain in the vicinity of the solid waste storage site. Eight of the wells contain tritium concentrations above the radioactivity concentration guide (RCG) for uncontrolled areas $(3000 \mathrm{pCi} / \mathrm{ml})$. The average concentration in these eight wells is approximately 100 times the RCG, and the concentration in the maximum well is 800 times the RCG. The total inventory of tritium in the ground water underlying the old 76-acre sector of the storage site is $250,000 \mathrm{Ci}$. About $1000 \mathrm{Ci}$ have migrated (via ground water movement) into an area of about 17 acres beyond the boundary fence southwest of the storage site. Because of the slow rate of travel of the ground water, most of the tritium will decay before outcropping in Four Mile Creek. When this tritium 


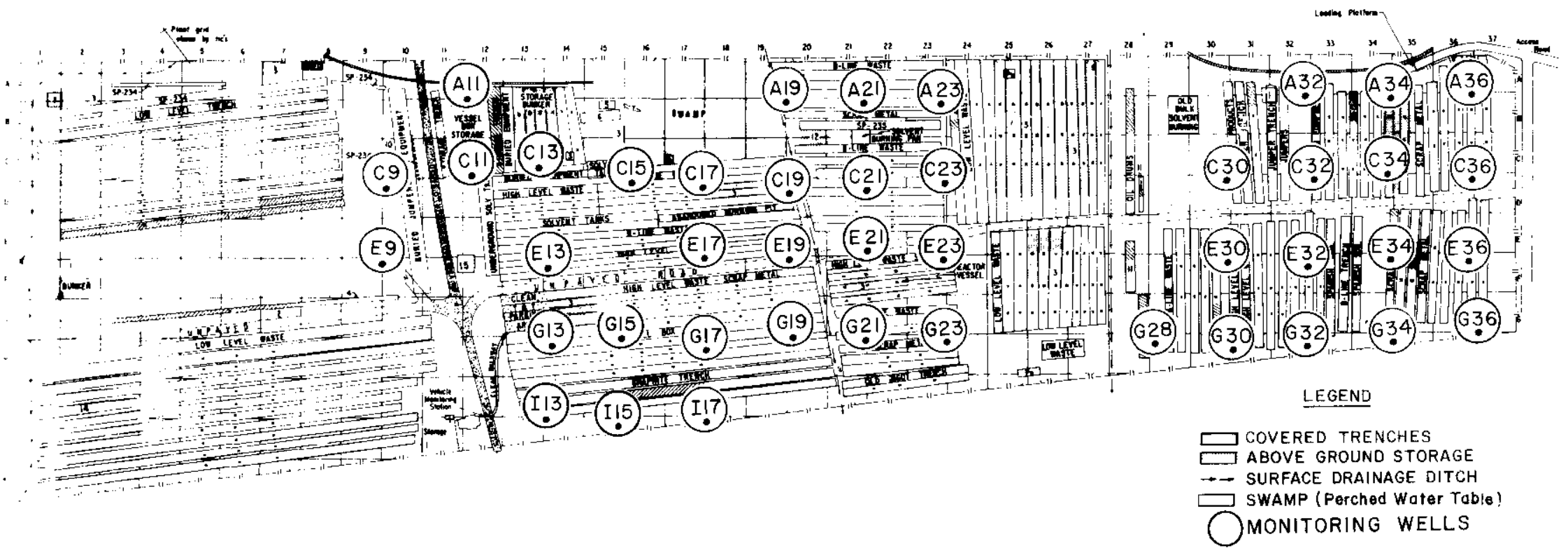

FIGURE 20. Monitoring Well Locations in Solid Radioactive Was te Storage Site in 1974 

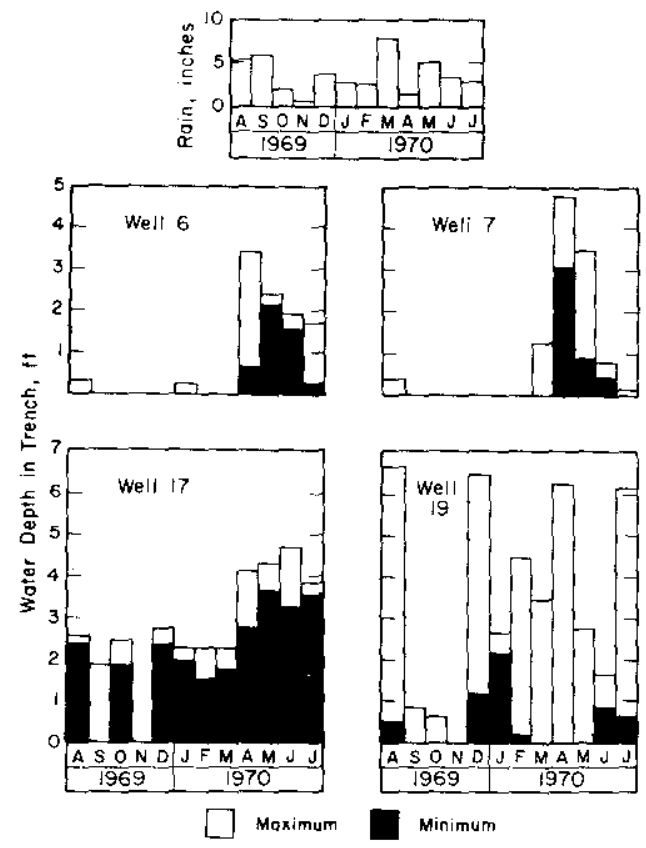

FIGURE 19. Water Levels in Backfilled Trenches

TABLE 6

Radionuclide Concentrations in Perched Water in the Bottom of Backfilled Trenches

\begin{tabular}{|c|c|c|c|c|c|c|c|c|c|c|c|c|}
\hline \multirow[t]{2}{*}{ Year } & \multicolumn{2}{|c|}{ WeZl $\theta$} & \multicolumn{2}{|c|}{ Weli 7} & \multicolumn{2}{|c|}{ wellog } & \multicolumn{2}{|c|}{ WeI2 17} & \multicolumn{2}{|c|}{ Wez2 19} & \multicolumn{2}{|c|}{ Hel2 2 2 } \\
\hline & $\operatorname{Max}$ & $A v_{G}$ & Max & $A v_{g}$ & $\operatorname{tax}$ & fivg & $\operatorname{Max}$ & $A v g$ & $\operatorname{Max}$ & Avg & $\max$ & Avg \\
\hline 1970 & 0.8 & 0.6 & 0.5 & 0.5 & & $a$ & 1.7 & 0.6 & 1.5 & 1.0 & & $a$ \\
\hline 1971 & 1.3 & 0.4 & 2.3 & 0.5 & & $a$ & 1.8 & 0.6 & 2.1 & 0.7 & & $\ddot{a}$ \\
\hline 1972 & 0.6 & 0.3 & 1.1 & 0.3 & & $\alpha$ & 2.3 & 0.7 & 1.6 & 0.8 & & $a$ \\
\hline 1973 & 1.7 & 0.5 & 2.0 & 0.6 & 4.1 & 1.7 & 4.0 & 1.1 & 2.4 & 1.2 & 1.8 & 0.9 \\
\hline 1974 & 5.4 & 1.5 & 1.0 & 0.4 & 7.4 & 2.4 & 11.0 & 5.0 & 4.0 & 2.2 & & $a$ \\
\hline 1975 & 4.0 & 1.9 & 2.7 & 0.8 & 5.4 & 2.9 & 2.7 & 0.7 & 5.0 & 2.8 & & $a$ \\
\hline \multirow{3}{*}{ Year } & \multicolumn{6}{|c|}{ Nonvolatiles Eeta Emititers, poilititer } & & & & & & \\
\hline & \multicolumn{2}{|c|}{ Well } & \multicolumn{2}{|c|}{ wel2 ? } & \multicolumn{2}{|c|}{ Weli $\&$} & \multicolumn{2}{|c|}{ WeZ2 17} & \multicolumn{2}{|c|}{ We $2 \underline{1} 13$} & \multicolumn{2}{|c|}{ WeZ2 23} \\
\hline & $\operatorname{Aax}$ & $A u_{i}$ & $\operatorname{Max}$ & $A v_{g}$ & $\operatorname{Max}$ & $A v g$ & $\max$ & $\log$ & $\operatorname{Max}$ & Aug & $H_{1} x<x$ & $\therefore i 0 g$ \\
\hline 1970 & 83 & 60 & 140 & 105 & & $a$ & 170 & 120 & 510 & 380 & & $a$ \\
\hline 1971 & 1250 & 330 & 1600 & 730 & & $a$ & 620 & 190 & 740 & 340 & & $a$ \\
\hline 1972 & 490 & 355 & 1260 & 950 & & $a$ & 390 & 150 & 930 & 290 & & $a$ \\
\hline 1973 & 530 & 260 & 1560 & 910 & 3240 & 1280 & 450 & 150 & 840 & 350 & 1070 & 930 \\
\hline 1974 & 1400 & 520 & 2000 & 1220 & 5960 & 2770 & 210 & 110 & 570 & 310 & & $a$ \\
\hline 1975 & 80 & 180 & 1010 & 770 & 3580 & 2400 & 160 & 130 & 820 & 400 & & $i$ \\
\hline
\end{tabular}

a. Well dry. 
TABLE 7

Radionuclide Concentrations in Monitoring Wel1s (1975 data)

Well $\frac{\mathrm{Cl}_{2} / 2}{\mathrm{Max}}$

\begin{tabular}{|c|c|c|c|}
\hline $\begin{array}{l}\text { Beta } \\
\text { Emit } \\
\text { pCi }\end{array}$ & & $\begin{array}{l}\text { Tritium, } \\
\text { pCi/m }\end{array}$ & \\
\hline Max & $A v g$ & $\operatorname{Max}$ & $\overline{A v g}$ \\
\hline 17 & 13 & $<50$ & $<50$ \\
\hline 9 & 2 & $<50$ & $<50$ \\
\hline 26 & 11 & 80 & 50 \\
\hline 32 & 11 & 110 & 90 \\
\hline 37 & 16 & 210 & 100 \\
\hline 12 & 4 & 80 & 60 \\
\hline 5 & 2 & 290 & 200 \\
\hline 3 & 1 & 8000 & 6900 \\
\hline 26 & 7 & 50 & 40 \\
\hline 56 & 15 & $<50$ & $<50$ \\
\hline 31 & 15 & $<50$ & $<50$ \\
\hline 68 & 26 & 60 & 50 \\
\hline 8 & 2 & 50 & 40 \\
\hline 31 & 8 & 160 & 70 \\
\hline 25 & 6 & 2000 & 1100 \\
\hline 32 & 6 & 430 & 360 \\
\hline 53 & 19 & 1600 & 1000 . \\
\hline 48 & 21 & 350 & 220 \\
\hline 11 & 6 & 2800 & 1400 \\
\hline 2 & 1 & 50 & 50 \\
\hline 11 & 4 & $<50$ & $<50$ \\
\hline 84 & 48 & $<50$ & $<50$ \\
\hline 46 & 17 & 8400 & 6900 \\
\hline 4 & 2 & 40 & 30 \\
\hline 0 & 0 & 100 & 60 \\
\hline 9 & 3 & 390 & 280 \\
\hline 18 & 7 & 110 & 80 \\
\hline 200 & 100 & 1000 & 480 \\
\hline 27 & 11 & 260 & 130 \\
\hline 44 & 14 & 57,000 & 40,000 \\
\hline 6 & 2 & 12,000 & 9000 \\
\hline 15 & 7 & 54,000 & 30,000 \\
\hline 18 & 8 & 170 & 150 \\
\hline 340 & 220 & $3,900,000$ & $2,400,000$ \\
\hline 7 & 2 & 18,000 & 12,000 \\
\hline 0 & 0 & 80 & 75 \\
\hline 18 & 10 & 70 & 60 \\
\hline 28 & 13 & 110,000 & 51,000 \\
\hline 16 & 4 & 1100 & 470 \\
\hline 7 & 2 & 1800 & 730 \\
\hline 280 & 180 & 90 & 80 \\
\hline 87 & 30 & 80 & 70 \\
\hline 20 & 5 & 80 & 40 \\
\hline
\end{tabular}


reaches Four Mile Creek, the maximum total dose-to-man will be 0.02 man-rem per year to a population of 70,000 people consuming Savannah River water. ${ }^{9}$

Sma1l concentrations of alpha and nonvolatile beta-gamma radioactivities were detected in seven of the wells (C-17, E-17, E-34, G-13, G-21, I-13, and I-17). The alpha and nonvolatile betagamna radioactivities in two of these, We1ls I-13 and I-17, are natural uranium and its decay products. The alpha and beta-gamma activities in four others (Wells $\mathrm{C}-17, \mathrm{E}-17, \mathrm{G}-13$, and G-21) are not attributable to migration from solid waste storage, but appear to be residual low-level contamination from spills of spent solvent from storage and burning operations during the period 1955 to 1968. The spills are estimated to have contained approximately $8 \mathrm{mCi}$ of plutonium and $\sim 150 \mathrm{mCi}$ of beta-gamma activity in about 600 gallons of solvent. The nonvolatile beta-gamma activity is primarily ${ }^{60} \mathrm{Co}$ in Well E-34.

\section{UPTAKE OF RADIONUCLIDES BY VEGETATION}

\section{General Principles}

Radioactivity on buried waste can be translocated to the ground surface by growing plants. ${ }^{10}$ Radiostrontium is the radionuclide most readily absorbed when plants are grown on soil contaminated with long-lived mixed fission products. Cesium-137 is relatively unavailable for plant uptake because of its strong fixation by the soil. Romney, et al. 1 found that radiostrontium accounted for 50 to $80 \%$ of the beta activity transferred to aboveground plant parts from soil mixed with solutions of mixed fission products. Less than $10 \%$ was attributable to ${ }^{106} \mathrm{Ru},{ }^{137} \mathrm{Cs}$, and ${ }^{44} \mathrm{Ce}$. Similar results were found by Anderson. ${ }^{12}$

Plutonium is only slightly available to plants.13,14 Cline ${ }^{13}$ found that the plutonium activity per gram of oven-dried tissue divided by the plutonium activity per gram of oven-dried soil was 0.0002 for ${ }^{239} \mathrm{Pu}$ when barley was growing on Cinebar soil under greenhouse conditions. Studies at SRL of plants grown under field conditions, where both uptake by plant roots of plutonium from the soil and deposition on the plant of plutonium associated with resuspended soil particles were potentially operable, gave values of 0.01 to 0.1 for the above activity ratio. 
The depth at which the radionuclide is buried influences its uptake by vegetation. 15,16 In general, the greater the depth of burial, the smaller the uptake by plants. The maximum depth that roots of native vegetation reach is not known, and considerable efforts to determine this have been unsuccessful, but root depth of some native vegetation is thought to be several times greater than the depth that waste is buried.

\section{SRP Experience}

SRP experience has shown that vegetation can absorb significant amounts of radionuclides from buried radioactive waste. Vegetation radiating $2100 \mathrm{mrad} / \mathrm{hr}$ at 2 inches was detected growing over backfilled burial trenches during the summer of 1965 . The radioactivity was due entirely to ${ }^{90} \mathrm{Sr}$ uptake from a buried evaporator vesse1 $\left(77 \mu \mathrm{Ci}{ }^{90} \mathrm{Sr} / \mathrm{g}\right.$ of soil) that was 2.2 feet beneath the soil surface. At another location in the same trench, radiation levels from vegetation were $210 \mathrm{mrad} / \mathrm{hr}$, and the region of greatest soil contamination $\left(76 \mu \mathrm{Ci}{ }^{90} \mathrm{Sr} / \mathrm{g}\right.$ of soil) was at a depth of 4.5 feet. In both cases, the contaminated vegetation was removed and additional backfill added over the trench.

Additional radioactive vegetation was found in the waste storage site during June 1968 (Table 8). The maximum ${ }^{90} \mathrm{Sr}$ reported was only $0.01 \%$ of that in 1965 and was found in the same area of the trench as in 1965. Gamna activity in several of the samples was slightly higher than that found routinely on vegetation at the burial ground fence. Alpha activity was within the same range as vegetation exposed only to fallout ( $1 \mathrm{pCi} / \mathrm{g} \max$.$) .$

\section{Controlling Vegetation Uptake}

Dispersal of radionuclides through vegetation uptake will negate the purpose of the radioactive waste storage site to contain radionuclides. Thus, deep-rooted vegetation should not be permitted to grow over the waste trenches. Continuing studies are evaluating both shallow-rooted grasses and several nonvegetative soil covers (Table 9 and Figure 21). Other alternatives include chemical and mechanical means of vegetation control. 
TABLE 8

Radioactivity in 1968 Vegetation

\begin{tabular}{|c|c|c|c|c|c|c|}
\hline \multirow[b]{4}{*}{ Isotope } & \multicolumn{6}{|c|}{ Concentration, $\mathrm{pCi}^{\mathrm{g}}$} \\
\hline & \multicolumn{4}{|c|}{$\begin{array}{l}\text { Solid Radioactive Waste } \\
\text { Storage Site }\end{array}$} & \multirow{2}{*}{\multicolumn{2}{|c|}{$\begin{array}{l}\text { General, } \\
F \text { and } H \\
\text { Areas }\end{array}$}} \\
\hline & \multirow{2}{*}{$\frac{\text { Within }}{\text { Avg }}$} & \multirow{2}{*}{$\frac{\text { Site }}{\text { Max }}$} & \multicolumn{2}{|c|}{ At Fence } & & \\
\hline & & & $A v g$ & $\operatorname{Max}$ & $\overline{A v g}$ & $\overline{\operatorname{Max}}$ \\
\hline${ }^{244} \mathrm{Ce}$ & 17 & 75 & 6.0 & 10.1 & 5.4 & 6.4 \\
\hline${ }^{137} \mathrm{Cs}$ & 12 & 140 & 2.0 & 3.1 & 1.5 & 1.8 \\
\hline${ }^{106} \mathrm{Ru}$ & 16 & 84 & 9.8 & 32.0 & 3.5 & 4.2 \\
\hline${ }^{95} \mathrm{Zr}-{ }^{95} \mathrm{Nb}$ & 3 & 17 & 1.9 & 2.6 & 1.6 & 2.3 \\
\hline${ }^{90} \mathrm{Sr}$ & 120 & 790 & 4.6 & 7.9 & $a$ & $a$ \\
\hline${ }^{54} \mathrm{Mn}$ & 25 & 260 & 0.6 & 0.6 & 0.6 & 0.6 \\
\hline
\end{tabular}

a. No analysis

\section{TABLE 9}

\section{Surface Covers Currently being Evaluated}

1. Herbicide, Hypalon ${ }^{a}$ sheet, asphalt, crushed stone

2. Herbicide, crushed stone

3. Herbicide, polyethylene sheet, asphalt, crushed stone

4. Herbicide, soil cement

5. Herbicide, polyethylene sheet, crushed stone, asphalt

6. Herbicide, Tedlar ${ }^{a}$ sheet, crushed stone

7. Herbicide, Hypaton ${ }^{\alpha}$ sheet, crushed stone, aspha1t

8. Herbicide, Hypazon ${ }^{a}$ sheet, crushed stone, asphalt

9. Herbicide, polyethylene sheet, crushed stone

10. Herbicide, asphalt, crushed stone

11. Crushed stone

a. Trademarks, E. I. du Pont de Nemours and Co., Wilmington, Delaware. 


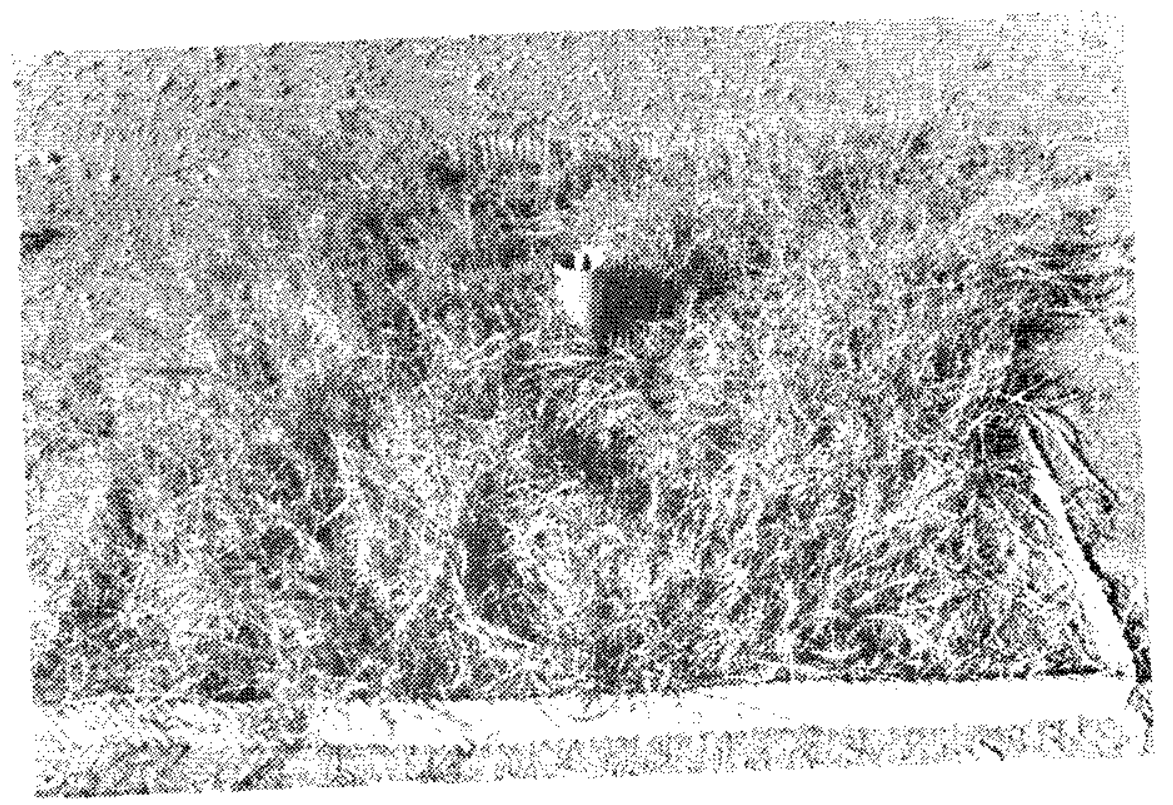

a. Vegetative

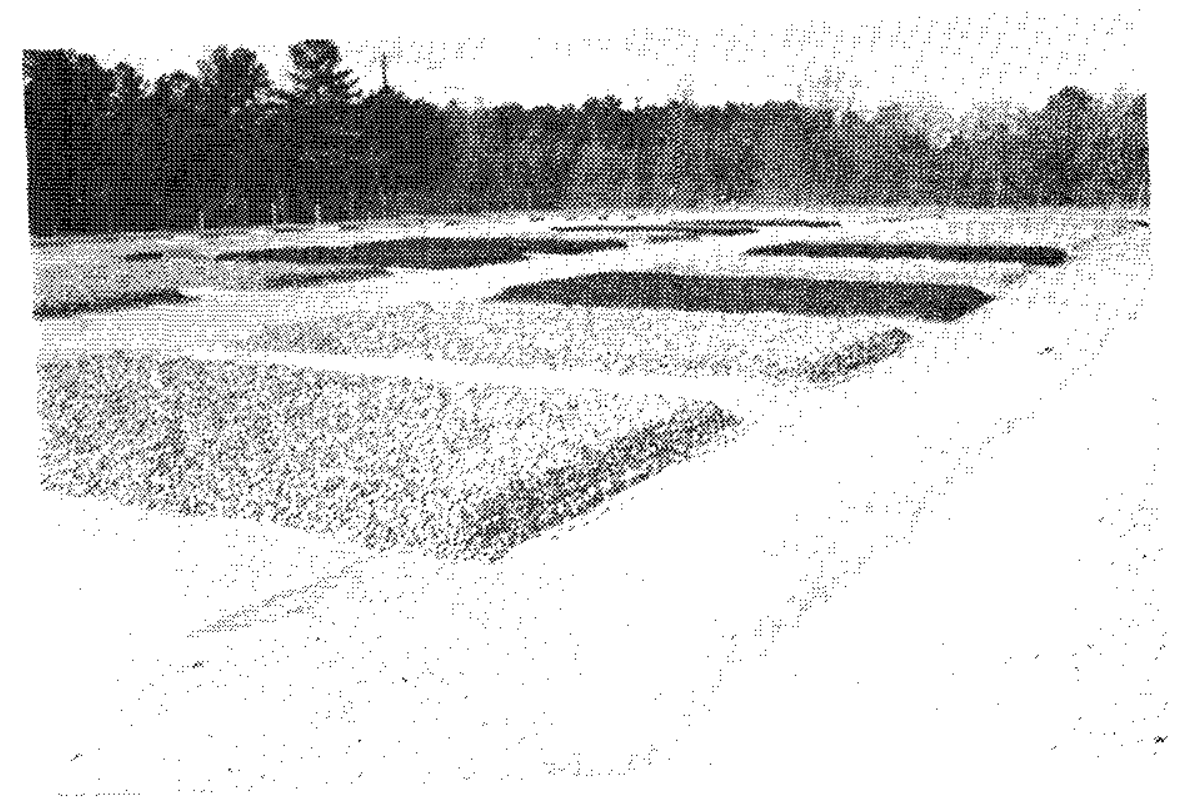

b. Nonvegetative maURE 21. Test plots for Evaluating soll
covers for Burial Trenches 


\section{CONCLUSIONS}

Radioactive waste management policies in the United States are undergoing continual revision. These changes necessitate a solid waste management program that not only meets present standards, but is also adaptable to future requirements. The SRP waste management procedures satisfy these criteria.

With the attention currently given to monitoring and control of migration, the solid wastes can remain safely in their present location for as long as is necessary for a national policy to be established for their eventual disposal. Leaching of fission product, activation product, and transuranium nuclides has been negligible. However, tritium is leaching from buried wastes. Because of the low movement rate of ground water, the dose-to-man projection from tritium leaching from the inventory in the burial trenches is estimated to be less than 0.02 man-rem per year. Uptake of radionuclides by vegetation growing over buried waste has shown that deep-rooted vegetation should not be permitted to grow over the waste. Thus, long-term (100 to 200 years) managment will primarily require vegetation and erosion control.

SRP waste management procedures for transuranium wastes are compatible with recovery and removal of buried solid wastes if national policy should so dictate. Segregation of waste according to source and radiation levels permits minimum management for much of the area and permits recovery of any one type of waste. Transuranium alpha emitters buried in concrete can be recovered without including soil. Detailed records of waste burial locations will facilitate recovery of wastes. 


\section{REFERENCES}

1. Project Crested Ice. Danish Atomic Energy Comission Report RISO 213, Research Establishment, Riso, Denmark (1970). 'Also published in: USAF Nuclear Safety 65, No. 1 (Part 2), special edition (Jan/Feb/Mar 1970).

2. G. E. Siple. Geology and Grownd Water of the Savannah River plant and Vicinity, South Carolina. U. S. Geological Survey Water-Supply Paper 1841, U. S. Govemment Printing Office, Washington, DC (1967).

3. T. M. Langley and W. L. Marter. The Savannah River Plant Site. USAEC Report DP-1323, E. I. du Pont de Nemours and Company, Savannah River Laboratory, Aiken, South Carolina (1973).

4. R. H. Hawkins and J. H. Horton. "Bentonite as a Protective Cover for Buried Radioactive Waste." Health Phys. 13, 287-292 (1967).

5. C. C. Haske11 and R. H. Hawkins. " $\mathrm{D}_{2} \mathrm{O}-\mathrm{Na}^{24}$ Method for Tracing Soil Moisture Movement in the Field." Soil Sci. Soc. Amer. Proceed. 28, 725-728 (1964).

6. J. H. Horton and R. H. Hawkins. "Flow Path of Rain From the Soil Surface to the Water Table." Soit Sci. 100, 377-383 (1965).

7. J. W. Fenimore. "Land Burial of Solid Radioactive Waste During a Ten-Year Period." Health Phys. 10, 229 (1964).

8. W. E. Prout. "Adsorption of Radioactive Wastes by Savannah River Plant Soil." Soil Sci. 86, 13-17 (1958).

9. R. H. Hawkins. "Migration of Tritium From a Nuclear Waste Burial Site." Presented at the Third ERDA Environmental Protection Conference, Chicago, Illinois, September 23-25, 1975.

10. A. C, Schuffelsen. "On the Radioactive Contamination of Soils and Crops." Agricultural and Public Health Aspects of Radioactive Contamination in Nomal and Emergency Situations. FAO Atomic Energy Series No. 5, pp 68-91, Food and Agriculture Organization of the United Nations, Rome (1964). 
11. E. M. Romney, H. Nishita, J. H. Olafson, and K. H. Larson. "Root Transfer of Fission Products From Contaminated Soil." Soil Sci. Soc. Amer. Proceed. 27, 383-385 (1963).

12. A. J. Andersen Investigations on the plant Uptake of Fission Products From Contaminated Soils. I. Influence of Plant Species and Soil Types on the Uptake of Radioactive Strontium and Cesium. Danish Atomic Energy Commission Report RISO 170, Research Establishment, Riso, Denmark (1967).

13. J. F. Cline. Uptake of ${ }^{241} A m$ and ${ }^{239} \mathrm{Pu}$ by Plants. USAEC Report BNWL-714, p 8.24, Batte1le Memorial Institute, Battelle Northwest Laboratory, Richland, Washington (1968).

14. J. H. Olafson and K. H. Larson. "Plutonium, Its Biology and Environmenta 1 Persistence," pp 633-639. V. Schultz and A. W. Klement, Jr., eds. Radioecology. Reinhold, New York (1963).

15. A. J. Andersen Investigations on the Plant Uptake of Fission Products From Contaminated Soils. II. The Uptake of Radioactive Strontium Placed at Different Depths in the Soil. Danish Atomic Energy Commission Report RISO 174, Research Establishment, Riso, Denmark (1967).

16. A. Troughton. The Underground Organs of Herbage Grasses. Bull. No. 44, Commonwealth Agricultural Bureau, England (1957) . 